\title{
Increased opioid dependence in a mouse model of panic disorder
}

\section{Xavier Gallego ${ }^{1}$, Patricia Murtra ${ }^{2,3}$, Teresa Zamalloa ${ }^{4}$, Josep Maria Canals ${ }^{5}$, Joseba Pineda ${ }^{4}$, Alejandro Amador-Arjona', Rafael Maldonado ${ }^{2}$ and Mara Dierssen ${ }^{1 *}$}

\author{
Genes and Disease Program, Genomic Regulation Center-CRG, Barcelona Biomedical Research Park-PRBB and CIBER de Enfermedades Raras, Barcelona, \\ Catalonia, Spain \\ 2 Unit of Neuropharmacology, Pompeu Fabra University, Barcelona, Catalonia, Spain \\ 3 Institute of Neuroscience, University of Miguel Hernández-CSIC, Alicante, Spain \\ ${ }^{4}$ Department of Pharmacology, University of the Basque Country, Leioa, Spain \\ ${ }^{5}$ Department of Cell Biology, Immunology and Neuroscience, University of Barcelona, Barcelona, Catalonia, Spain
}

Edited by:

Agnes Gruart, University Pablo de

Olavide, Spain

\section{Reviewed by:}

Shashana Eitan, Texas A\&M University, USA

\section{${ }^{*}$ Correspondence:}

Mara Dierssen, Genes and Disease

Program, Genomic Regulation

Center-CRG, Barcelona Biomedical

Research Park-PRBB, C/Dr. Aiguader,

88, E-08003 Barcelona, Catalonia,

Spain.

e-mail:mara.dierssen@crg.es
Panic disorder is a highly prevalent neuropsychiatric disorder that shows co-occurrence with substance abuse. Here, we demonstrate that TrkC, the high-affinity receptor for neurotrophin3 , is a key molecule involved in panic disorder and opiate dependence, using a transgenic mouse model (TgNTRK3). Constitutive TrkC overexpression in TgNTRK3 mice dramatically alters spontaneous firing rates of locus coeruleus (LC) neurons and the response of the noradrenergic system to chronic opiate exposure, possibly related to the altered regulation of neurotrophic peptides observed. Notably, TgNTRK3 LC neurons showed an increased firing rate in saline-treated conditions and profound abnormalities in their response to met ${ }^{5}$-enkephalin. Behaviorally, chronic morphine administration induced a significantly increased withdrawal syndrome in TgNTRK3 mice. In conclusion, we show here that the NT-3/TrkC system is an important regulator of neuronal firing in LC and could contribute to the adaptations of the noradrenergic system in response to chronic opiate exposure. Moreover, our results indicate that TrkC is involved in the molecular and cellular changes in noradrenergic neurons underlying both panic attacks and opiate dependence and support a functional endogenous opioid deficit in panic disorder patients.

Keywords:TgNTRK3, NT-3, TrkC, BDNF, TrkB, panic disorder, opiate withdrawal, locus coeruleus

\section{INTRODUCTION}

There is a high rate of co-occurrence between substance abuse and other psychiatric disorders (Regier et al., 1990; Kessler et al., 1994; Kandel et al., 2001) such as anxiety and panic disorder (Cottler et al., 1992; Kushner et al., 2000; Breslau et al., 2003; Zvolensky et al., 2005, 2006). Based on clinical data, it has been proposed that deregulation of the opioid system at the brainstem level may potentially underlie critical aspects of panic disorder's neurobiology including respiratory abnormalities and sensitivity to suffocation. The locus coeruleus (LC) underlies the physiologic and affective changes seen in opiate withdrawal and in panic attacks (Aghajanian, 1978; Aghajanian and Wang, 1986; Gear et al., 1995; El-Kadi and Sharif, 1997; Nakai et al., 2002) and could be a common structure for both processes so that withdrawal syndrome and panic attacks may be different symptomatic expressions of similar neurobiological mechanisms. So, in subjects with overactivity of endogenous opioid system, naltrexone might induce panic attacks by removing this inhibitory effect (Aghajanian, 1978; Arntz et al., 1993; Maremmani et al., 1998; Sinha et al., 2007) on noradrenergic neurons in the LC. Moreover, studies focused on the treatment of pain, the most frequent fear of dying patients have used morphine to reduce states of panic (Roller, 2000), as well in studies with rats in which morphine administration inhibited the dorsal periaqueductal grey (dPAG), a brain region responsible for the escape behavior that is thought to be related to fear and panic (Nicolas et al., 2007).
In recent years, several lines of evidence have established the relationship of neurotrophins with both anxiety and drug abuse disorders (Chao, 2003; Chao et al., 2006). This peptide family includes nerve growth factor, brain-derived neurotrophic factor (BDNF), neurotrophin-3 (NT-3), neurotrophin-4/5 (Binder and Scharfman, 2004). Neurotrophins selectively interact with their individual highaffinity protein kinase receptors of the Trk family (Kaplan and Miller, 2000; Chao, 2003; Teng and Hempstead, 2004), so that BDNF and NT-3 mediate their biological effects via TrkB and TrkC highaffinity receptors respectively (Dechant and Barde, 2002). Human genetic studies have recently confirmed the association of BDNF gene variants and the NTRK2 gene to substance-related and other neuropsychiatric disorders (Zhang et al., 2006; Gratacos et al., 2007). Moreover, BDNF and NT-3-signaling pathways participate in opiate-induced adaptations of the catecholaminergic system in vitro (Sklair-Tavron and Nestler, 1995) and in vivo (Berhow et al., 1995; Sklair-Tavron et al., 1996). In mice with conditional ablation of NT-3 in brain, the somatic symptoms of opiate withdrawal are attenuated, in conjunction with reduced upregulation of tyrosine hydroxylase (TH) expression in LC (Akbarian et al., 2001). This phenotype is restored by transgene-derived NT-3 expression. On the other hand, the LC expresses high levels of the mRNAs of BDNF and NT-3 and their high-affinity receptors (Seroogy et al., 1994; Smith et al., 1995; Zhang et al., 1998) and both neurotrophins increase survival of LC neurons in vitro (Friedman et al., 1993; 
Sklair-Tavron and Nestler, 1995). Noradrenergic LC neurons of BDNF-deficient mice respond to chronic morphine treatment with a paradoxical down regulation of CAMP-mediated excitation and lack of dynamic regulation of $\mathrm{TH}$, and these mice also have reduced opiate withdrawal symptoms despite normal antinociceptive tolerance (Akbarian et al., 2002).

In the present study, we have used transgenic mice overexpressing TrkC (TgNTRK3), a model of panic disorder (Dierssen et al., 2006; Sahún et al., 2007b), to test the hypothesis that the LC opioid system might be altered with an impact on opiate dependence as previously suggested in human patients.. We have characterized the behavioral and electrophysiological responses to acute and chronic morphine treatment and during opiate withdrawal along with the changes in expression of BDNF, NT-3 TrkB and TrkC mRNAs. Our work highlights the implication of $\mathrm{TrkC}$ in panic disorder and substance abuse.

\section{MATERIALS AND METHODS ANIMALS}

Same sex hybrid B6/SJL-F1J mice were housed in groups of 3-5 animals per cage in standard Macrolon ${ }^{\circledR}$ cages $(40 \mathrm{~cm}$ long $\times 25 \mathrm{~cm}$ wide $\times 20 \mathrm{~cm}$ high) under a $12 \mathrm{~h}$ light/dark schedule (lights on 08:00 to 20:00) in controlled environmental conditions of humidity $(50 \%-70 \%)$ and temperature $\left(22 \pm 2^{\circ} \mathrm{C}\right)$ with food and water supplied ad libitum. The production TgNTRK3 mice has previously been described (Dierssen et al., 2006). Briefly, TgNTRK3 mice were obtained as heterozygotes on a B6/SJL-F1J genetic background (Charles River, Barcelona, Spain). Hybrid founders were crossed using B6/SJL-F1J females and all experiments were performed using male mice from the F16-F20 generation to attenuate littermate's genetic differences. The non-transgenic (WT) littermates obtained from crosses of males TgNTRK3 mice and B6/SJL-F1J females served as controls. All experimental procedures were approved by the local ethics committee (CEEA-IMIM and CEEA-PRBB), and met the guidelines of the local (Catalan law 5/1995 and Decrees 214/97, 32/2007) and European regulations (EU directives 86/609 and 2001-486) and the Standards for Use of Laboratory Animals $n^{\circ}$ A5388-01 (NIH). The CRG is authorized to work with genetically modified organisms (A/ES/05/I-13 and A/ES/05/14).

\section{DRUGS}

Morphine was provided by the Ministerio de Sanidad y Consumo (Spain). Naloxone and $\mathrm{Met}^{5}$-enkephalin (ME) was purchased from Sigma Chemical Co. (Madrid, Spain). Both compounds were dissolved in physiological saline $(0.9 \% \mathrm{NaCl})$.

\section{CHARACTERIZATION OF THE TgNTRK3 BEHAVIORAL RESPONSE TO OPIATES}

For the pharmacological in vivo study of opiate effects in TgNTRK3 mice we used 15-20 male mice of 2-4 months of age per group of treatment and genotype.

\section{Acute effects of morphine}

We evaluated the acute effects of morphine $(10 \mathrm{mg} / \mathrm{kg}$, s.c.) on nociception using the tail immersion and hot plate tests and on locomotion in WT and TgNTRK3 mice. For the hot plate test we used different doses of morphine in order to avoid a ceiling effect
$(2.5,5$, and $10 \mathrm{mg} / \mathrm{kg}$, s.c.). For the tail immersion test, mice were gently placed in a restrainer cylinder and the nociceptive threshold was assessed as described previously (Florez et al., 1990; Ruiz et al., 1993; Simonin et al., 1998) by measuring the time to withdraw the tail immersed in a thermostatically controlled water bath $\left(50 \pm 0.1^{\circ} \mathrm{C}\right.$; Clifton, Scientific Instruments, England), with a cutoff latency of $15 \mathrm{~s}$ to prevent tissue damage. We also used a hot plate analgesic meter (Columbus, $\mathrm{OH}$, USA) that consisted of a glass cylinder (19-cm high, $19-\mathrm{cm}$ diameter) to keep the mice on the heated surface of the plate $\left(52 \pm 0.1^{\circ} \mathrm{C}\right)$. Two nociceptive indexes, licking of the paws and jumping, were registered. The cutoff latency was of $30 \mathrm{~s}$ for the licking response and of $240 \mathrm{~s}$ for the jumping response, respectively. Locomotor responses were evaluated using activity boxes $(9 \mathrm{~cm}$ long $\times 20 \mathrm{~cm}$ wide $\times 11 \mathrm{~cm}$ high; Imetronic, Lyon, France); with a line of photocells $2 \mathrm{~cm}$ above the floor to measure horizontal movements and another line located $6 \mathrm{~cm}$ above the floor to measure vertical activity (rearing). On the testing day, the mice were individually placed in the boxes and the total locomotor activity (ambulatory movements plus horizontal movements) was recorded for $30 \mathrm{~min}$ in a low luminosity environment (5-15 Lux).

In order to habituate the animals to the test environment and to obtain a stable baseline, tail immersion response and locomotor activity were measured for 2 days before the experiment. Saline injections were given on these days. On the experimental day, locomotor activity was evaluated immediately after morphine injection $(10 \mathrm{mg} / \mathrm{kg}$, s.c.) during $30 \mathrm{~min}$. Then, tail immersion test was performed, followed by the hot plate test.

\section{Tolerance and sensitization to morphine effects}

Tolerance refers to drug-induced adaptations that lead to diminishing effects of a constant, repeated drug dose. Sensitization, or reverse tolerance, refers to drug-induced adaptations that enhance drug responsiveness with repeated drug exposure (Dierssen et al., 1990). Morphine causes both tolerance and sensitization, with antinociceptive effects decreasing over time while locomotor activity increases. As for the previous experiment, basal tail immersion response and locomotor activity were evaluated for 2 days before the initiation of the chronic morphine treatment on day 1 . Morphine (10 mg/kg, s.c.) was administered chronically twice a day (12 h inter-injection interval) for 7 days. Locomotor activity was recorded immediately after the morning injection of morphine, as described above. Changes in nociceptive threshold were assessed 30 min later using the tail immersion test (days 1-7).

\section{Naloxone-precipitated morphine withdrawal}

The naloxone-precipitated withdrawal syndrome in morphinedependent mice was evaluated as previously described (Maldonado, 1997). Briefly, behavioral ratings were calculated over a $15 \mathrm{~min}$ period by a trained observer blind to the genotype. The animals were placed individually into test chambers consisting of transparent plastic cylinders ( $50 \mathrm{~cm}$ high, $30 \mathrm{~cm}$ diameter) with a white floor, to evaluate the behavioral signs of withdrawal. Behavioral responses were recorded in two sessions: 15 min before naloxone injection and the $30 \mathrm{~min}$ after injection. Wet dog shakes, jumping, paw tremor and sniffing were quantified. Ptosis, diarrhea, teeth chattering, body tremor and piloerection were evaluated over 
5 min periods with the presence of each sign during each period being scored as 1 . The numbers of periods showing each sign were then counted (maximum score $=6$ ). A global withdrawal score, determined by all the checked signs was calculated individually for each mouse. To obtain this global value and to assign a proportional weight to all the signs, the score obtained from each sign was multiplied by a constant as previously reported (Maldonado et al., 1996). Naloxone-precipitated withdrawal was evaluated after two different treatment regimes of morphine as follows in order to avoid ceiling effects on withdrawal symptoms that would blind possible differences between genotypes.

Naloxone-precipitated morphine withdrawal after increasing doses of morphine. Morphine was injected i.p. twice a day (12-h inter-injection interval) for 6 days. The morphine dose was progressively increased as follows: 1 st day, $20 \mathrm{mg} / \mathrm{kg} / \mathrm{injec}-$ tion??; 2nd day, $40 \mathrm{mg} / \mathrm{kg}$; $3 \mathrm{rd}$ day, $60 \mathrm{mg} / \mathrm{kg} ; 4$ th day, $80 \mathrm{mg} / \mathrm{kg}$; 5 th day, $100 \mathrm{mg} / \mathrm{kg}$; 6 th day (only morning injection), $100 \mathrm{mg} / \mathrm{kg}$. Control mice of both genotypes were treated with saline using the same injection schedule. Withdrawal was precipitated in each animal by injecting naloxone $(1 \mathrm{mg} / \mathrm{kg}$, s.c.) $2 \mathrm{~h}$ after the last morphine administration.

Naloxone-precipitated morphine withdrawal after constant dose of morphine. Morphine was injected i.p. twice a day (12-h interinjection interval) for 6 days. In this experimental group, the dose of morphine was constant ( $20 \mathrm{mg} / \mathrm{kg} /$ injection?) during the 6 days. Control mice of both genotypes were treated with saline using the same injection schedule. Withdrawal was precipitated in each animal by injecting naloxone ( $1 \mathrm{mg} / \mathrm{kg}$, s.c.), $2 \mathrm{~h}$ after the last morphine administration.

Anxiety-like behavior during morphine withdrawal. The anxiogenic effects of morphine withdrawal were studied using the zeromaze test immediately after evaluation of withdrawal symptoms, in animals receiving constant doses of morphine $(20 \mathrm{mg} / \mathrm{kg}$; see Naloxone-precipitated morphine withdrawal after constant dose of morphine). The zero-maze consisted of a circular path (runway width $5.5 \mathrm{~cm}, 46 \mathrm{~cm}$ diameter) with two open and two closed segments (walls $8 \mathrm{~cm}$ high) and was elevated $50 \mathrm{~cm}$. Animals were placed into the closed segments and their movements analyzed for $5 \mathrm{~min}$. The experiment was carried out in a dimly lit room to minimize any effects of stress/anxiety and data were scored with the aid of a video camera. The latency to enter the open segment, the number of crossings and the time spent in the open segments were recorded. An open segment visit was scored when the mouse moved all four paws into the segment.

\section{IN SITU HYBRIDIZATION}

Three TgNTRK3 and 3 WT littermates were used for each treatment condition following the increasing dose morphine injection schedule detailed in Section "Naloxone-precipitated morphine withdrawal after increasing doses of morphine". Animals were killed $2 \mathrm{~h}$ after naloxone injection to study morphine withdrawal or $4 \mathrm{~h}$ after the last morphine injection to study chronic morphine effects. The same schedule was used in the saline-treated group. Then, brains were dissected out and frozen in dry ice and serial coronal cryostat sections $(14 \mu \mathrm{m})$ were processed for $\operatorname{TrkB}$, TrkC, NT-3, and BDNF riboprobes as follows. After rinsing in PBS, tissue was deproteinated in $0.2 \mathrm{M} \mathrm{HCl}$ for $10 \mathrm{~min}$, acetylated with $0.25 \%$ acetic anhydride in $0.1 \mathrm{M}$ ethanolamine for $10 \mathrm{~min}$, post-fixed in $4 \%$ paraformaldehyde, and dehydrated with increasing concentrations of ethanol. Slices were incubated for $16 \mathrm{~h}$ in a humidified chamber at $53^{\circ} \mathrm{C}$ with $3 \times 105$ c.p.m. of antisense probes in $150 \mu \mathrm{L}$ of hybridization cocktail ( $50 \%$ formamide, $20 \mathrm{mM}$ Tris- $\mathrm{HCl}, \mathrm{pH}$ 7.6, 1 mM EDTA, pH 8.0, 0.3 M NaCl, 0.1 M dithiothreitol, $0.5 \mathrm{mg} /$ $\mathrm{mL}$ yeast tRNA, $0.1 \mathrm{mg} / \mathrm{mL}$ poly $(\mathrm{A}+) \mathrm{RNA}, 1 \times$ Denhardt's solution, and $10 \%$ dextran sulfate). Antisense cRNA probes to detect the transcript were prepared by in vitro transcription using T7 RNA polymerase (Promega, WI, USA) and [35S] UTP (Amersham Pharmacia Biotech, Uppsala, Sweden). The TrkB probe recognized both full-length and truncated isoforms (Lindefors et al., 1995) and the TrkC probe detected all TrkC receptor forms (Laurenzi et al., 1994). For control experiments, sense cRNA probe was obtained by in vitro transcription using T3 RNA polymerase (Promega, WI, USA). After hybridization, slices were first washed at room temperature in $1 \times \mathrm{SSC}$, followed by two washes in $1 \times \mathrm{SSC}$ at $37^{\circ} \mathrm{C}$ for 15 min each. Single-stranded RNA was digested by RNase treatment $(40 \mu \mathrm{g} / \mathrm{mL})$ for $30 \mathrm{~min}$ at $37^{\circ} \mathrm{C}$ in $0.5 \mathrm{M} \mathrm{NaCl}, 20 \mathrm{mM}$ Tris$\mathrm{HCl}, \mathrm{pH} 7.6$, and $2 \mathrm{mM}$ EDTA. Tissue was washed twice in $1 \times \mathrm{SSC}$ in $65^{\circ} \mathrm{C}$ for $10 \mathrm{~min}$, dehydrated in ethanol, and air-dried. Slices were exposed to $\beta$-max x-ray film (Amersham Pharmacia Biotech, Uppsala, Sweden) for 20 days and dipped in LM-1 photoemulsion (Amersham Pharmacia Biotech, Uppsala, Sweden), exposed at $4^{\circ} \mathrm{C}$ for 2 months, developed with D19 (Eastman Kodak), fixed, and counterstained with cresyl violet staining. Consecutive slices were stained against TH in order to delimit the LC and thus allowing an accurately quantification of this region.

\section{QUANTITATIVE-PCR}

To determine changes in endogenous TrkC receptors [full length (TrkC FL) and truncated (TrkC TF)], quantitative-PCR was carried out in duplicate in brainstem from adult (2-4 month of age) TgNTRK3 $(n=4)$ and WT mice $(n=3)$ with the cDNA solution using the LightCycler ${ }^{\circledR} 480$ SYBR Green I Master kit (Roche Diagnostics GmbH, Mannheim, Germany) in a LightCycler ${ }^{\circledR} 480$ Real-Time PCR system (Roche Diagnostics GmbH, Mannheim, Germany) according to the manufacturer's recommendations, except that the final volume of the reaction was $20 \mu \mathrm{L}$ in order to avoid errors due to high volumes. The cDNA solution was submitted to 45 cycles of PCR amplification by using specific primers from the endogenous TrkC: TrkC FL -F 5' - ACCGGAAGTTCACCACAGAG $-3^{\prime}$ and TrkC FL -R 5'- GCAGACTCTGGGTCTCTCCA -3'; TrkC TF -F 5' - CCAGAGTGGGGATGTGTCTT - $3^{\prime}$ and TrkC TF -R 5'CCATGGTTAAGAGGCTTGGA - $3^{\prime}$. The Pgk1 gene was used as the reference gene. Final volume was $20 \mu \mathrm{L}$, with $1 \mu \mathrm{L}$ of one-tenth $\mathrm{H} 2 \mathrm{O}$-diluted cDNA from reverse transcription reaction, $0.3 \mu \mathrm{mol} / \mathrm{L}$ of each specific primer, and $10 \mu \mathrm{L} 2 \times$ SYBR Green I Master solutions. Quantitative-PCR cycles were set at $10 \mathrm{~min}$ denaturation followed by 45 cycles of $95^{\circ} \mathrm{C}$ for $10 \mathrm{~s}, 61^{\circ} \mathrm{C}$ for $15 \mathrm{~s}$, and $72^{\circ} \mathrm{C}$ for $10 \mathrm{~s}$ and $95^{\circ} \mathrm{C}$. Dissociation curves were inspected for each pair of primers, and only dissociation peak must be present for each run of reaction before the results were considered to be valid. A 4-fold serial dilution of a reference sample was used for construction of 
standard curves with respect to each pair of primers. All samples were amplified in duplicate and the CT mean was obtained for further calculations. Duplicates with SD $\geq 0.38$ were excluded, and the corresponding samples were re-amplified. The $\Delta \Delta \mathrm{Ct}$ method [Relative Expression Software Tool (REST)] was used to quantify the relative amount of mRNA in each sample in comparison with the control samples. Next, $2-\Delta \Delta \mathrm{Ct}$ of each gene was transformed into logarithmic scale ( $\log 2$ ratio).

\section{ELECTROPHYSIOLOGICAL STUDIES}

Single-unit extracellular recordings of LC neurons were performed in slices from saline treated (WT $n=16$ and TgNTRK3 $n=12$ ) and morphine-treated (WT $n=16$; $\operatorname{TgNTRK} 3 n=16$ ) mice, as previously described (Pineda et al., 1996) and following the increasing dose morphine injection schedule of Section "Naloxone-precipitated morphine withdrawal after increasing doses of morphine". Briefly, mice were anesthetized with chloral hydrate $(400 \mathrm{mg} / \mathrm{kg}$, i.p.) and decapitated $1-4 \mathrm{~h}$ after the last injection of morphine. Coronal slices $(400 \mu \mathrm{m})$ of the brainstem including the LC were prepared with a vibratome and incubated in a Haas-type gas-liquid interface chamber at $33^{\circ} \mathrm{C}$, which was continuously perfused with artificial cerebrospinal fluid (aCSF) at a flow rate of $1-1.5 \mathrm{~mL} / \mathrm{min}$ (saturated with $95 \% \mathrm{O}_{2} / 5 \%$ $\mathrm{CO}_{2}$ ). The aCSF was composed of: $129 \mathrm{mM} \mathrm{NaCl}, 3 \mathrm{mM} \mathrm{KCl}$, $1.25 \mathrm{mM} \mathrm{NaH}_{2} \mathrm{PO}_{4}, 2 \mathrm{mM} \mathrm{MgSO}_{4}, 2 \mathrm{mM} \mathrm{CaCl}_{2}, 22 \mathrm{mM} \mathrm{NaHCO}_{3}$ and $10 \mathrm{mM}$ D-glucose. The extracellular signal was recorded by blunt-tipped Omegadot glass micropipettes filled with a $50 \mathrm{mM}$ $\mathrm{NaCl}$ solution (3-5 M $\Omega$ ), and then monitored through a highinput impedance amplifier on an oscilloscope and also with an audio unit. Individual neuronal (single-unit) spikes were isolated from the background noise with a window discriminator and the firing rate was analyzed by means of a PC-based custom-made program, which generated rate bar histograms in consecutive 10-s bins (HFCP ${ }^{\circledR}$, Cibertec S.A., Madrid, Spain). The LC was identified visually in the rostral pons as a dark oval area on the lateral borders of the central gray and the 4 th ventricle, immediately anterior to the genu of the facial nerve. LC cells displayed spontaneous firing activity at regular rhythms and long-lasting positive-negative waveforms.

Opioid withdrawal was spontaneously precipitated in vitro on the slice preparation in chronic morphine-treated mice of both genotypes by allowing morphine to wash out for $90 \mathrm{~min}$ before recordings (Kogan et al., 1992). Next, consecutive neurons were sampled during in vitro opiate withdrawal for about $90 \mathrm{~min}$ by multiple electrode tracks randomly positioned within the LC. Complete washout of residual morphine was confirmed at the end of each experiment by testing the lack of naloxone $(1 \mu \mathrm{M})$ effect. To evaluate opiate tolerance in the LC, concentration-effects curves were constructed for the inhibitory effect of the $\mu$-opioid receptor (MOR) agonist ME on the LC in saline and chronic morphine-treated mice of both genotypes following the increasing dose morphine injection schedule of Section "Naloxone-precipitated morphine withdrawal after increasing doses of morphine". Increasing concentrations of ME $(0.1-100 \mu \mathrm{M})$ were added at 5 min intervals until a maximal effect was reached. ME was chosen because its washout is very rapid even at high concentrations and its action is mediated almost exclusively by MOR in the LC (Williams and North, 1984).

\section{DATA ANALYSIS AND STATISTICAL EVALUATION}

All values are given as mean \pm SEM. For the behavioral studies, data obtained from the tail immersion and the hot plate tests were expressed as the percentage of maximal possible effect (\% MPE). The calculation of the \% MPE was performed using the following formula: [(test latency - control mean latency)/(cutoff - control mean latency) $] \times 100$. For data obtained from acute morphine administration, a two-way analysis of variance (ANOVA) was used to determine the interaction between genotype and treatment. Posterior Student's $t$ test was used to determine differences between TgNTRK3 and WT mice. The development of tolerance to morphine antinoception in the tail immersion test and the development of locomotor sensitization in activity cages were analyzed by using a General Linear Model - Repeated Measures analysis in order to detect differences between curves across days. Two-way ANOVA was used to determine the interaction between treatment and genotype. Data related to the total score obtained from withdrawal signs were analyzed by using Student's $t$ test. Levels of NT-3, $\mathrm{BDNF}$ and their receptors, $\operatorname{TrkC}$ and $\operatorname{TrkB}$ mRNAs were analyzed by using one-way ANOVA for the treatment and Student's $t$ test for the genotype. Bonferroni post hoc was used when necessary. Results from quantitative RT-PCR analysis were obtained in the Relative Expression Software Tool - 384 (REST-384@ v.2), and analyzed using Pair Wise Re-allocation Randomisation Test@

For the electrophysiological studies, the basal firing rate was obtained in each cell by averaging the values from the rate bars recorded for at least $60 \mathrm{~s}$ in the absence of any drug, so that the stability of the discharge was ensured. To evaluate opiate withdrawal in the LC, the mean firing rate of all cells sampled in each slice was considered as an individual data point and used for the statistical analysis. The inhibitory effect of each ME concentration was calculated as the percentage of the reduction of firing rate from the baseline. In these assays, the firing rates after each ME application was the average value obtained from the rate bars in 9 consecutive bins after the onset of the perfusion. Curve fitting analysis was performed by the computer program GraphPad Prism (version 3.0 for Windows, San Diego, USA) to obtain the best simple nonlinear fit to the following three-parameter logistic equation: $\mathrm{E}=\mathrm{Emax} /\left[1+\left(\mathrm{EC}_{50} / \mathrm{A}\right)^{n}\right]$, where $\mathrm{E}$ is the effect induced by each concentration of $\mathrm{ME}(\mathrm{A})$, Emax is the maximal effect, $\mathrm{EC}_{50}$ is the concentration of the agonist needed to elicit a $50 \%$ of the maximal effect and $n$ is the slope factor of the concentration-effect curve. Emax was constrained to be $100 \%$ since the maximal inhibition was always complete. For statistical analysis, the $\mathrm{EC}_{50}$ values were transformed to the corresponding logarithmic data to convert them to a Gaussian distribution. Data among groups were compared by one-way ANOVA followed, when significant, by a Student's $t$ test (for concentration-effect curve parameter evaluations) or a Tukey's multiple comparison $t$ test (for firing rate evaluations). Probability values lower than 0.05 were accepted as significantly different.

\section{RESULTS}

\section{THE ACUTE ANTINOCICEPTIVE EFFECTS OF MORPHINE WERE SLIGHTLY} ATTENUATED IN TgNTRK3

The acute effects of morphine were evaluated by the changes induced in nociception (Figure 1) and locomotor activity (Figure 2A). In the hot plate test, two-way ANOVA revealed no interaction between 


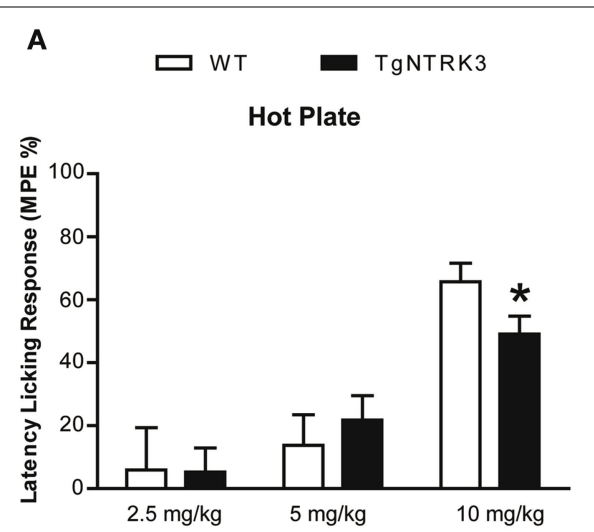

\section{B}

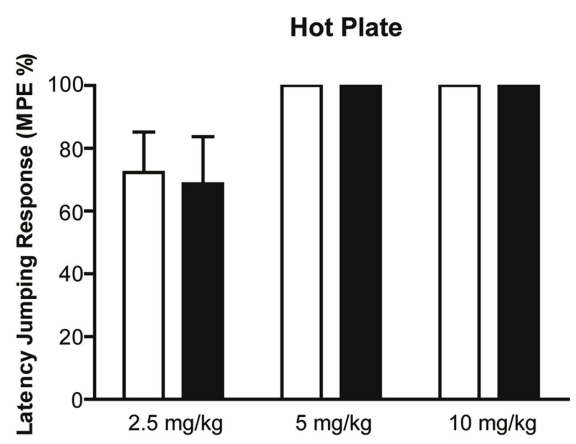

C

Tail Inmersion

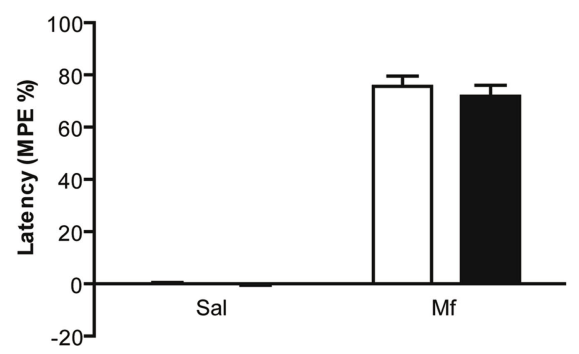

FIGURE 1 |Acute antinociceptive effect of morphine (Mf, 10 mg/kg, s.c.). Two behavioral tests were used in WT (white bars) and TgNTRK3 (black bars): the hot plate test in which $(\mathbf{A})$ the licking and $(\mathbf{B})$ the jumping threshold were recorded, and $(\mathbf{C})$ the tail immersion test where the tail withdrawal latency is given. Antinociceptive effects were evaluated $30 \mathrm{~min}$ after morphine injection. Data are expressed as means \pm SEM of the maximum possible effect (MPE \%). ${ }^{*} p<0.05$ (Student's $t$ test, WT vs. TgNTRK3 mice).

\section{A}

\section{Locomotor activity}

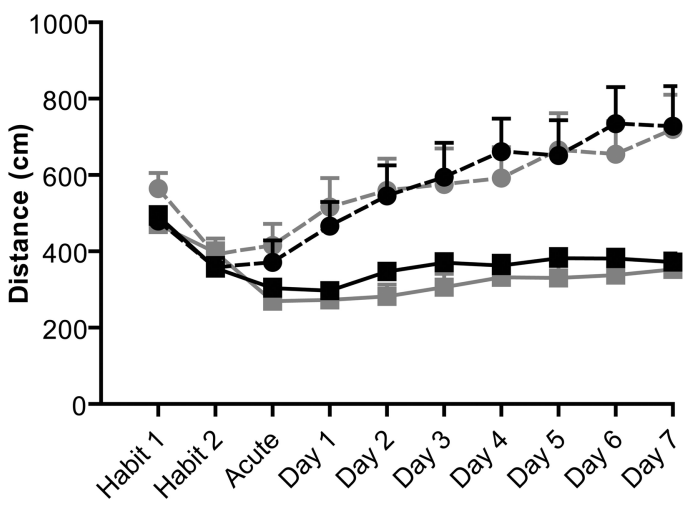

FIGURE 2 |Tolerance to morphine-induced antinociception and sensitization to locomotor effects. Mice received repeated morphine (10 mg/kg, s.c.) or saline injections twice a day for 7 days. (A) Locomotor activity was measured in activity cages during 30 min after the morning injection of morphine during 7 days. (B)
B

\section{Tail Inmersion}

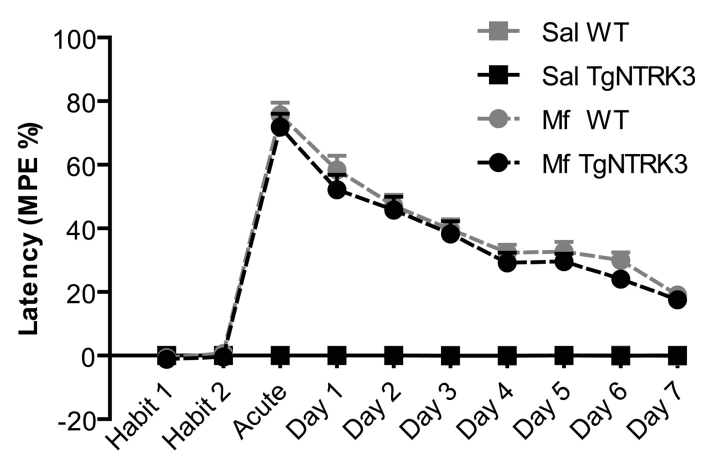

Nociceptive threshold was determined during the 7 days of morphine administration after measuring locomotor activity, by means of the tail immersion test. Data are expressed as means \pm SEM of the maximum possible effect (MPE $\%)$ for the antinociceptive effect or the distance traveled (cm) for locomotor activity. genotype and treatment in any of the responses $\left(F_{(2,89)}=0.04\right.$, n.s., jumping, and $F_{(2,89)}=1.27$, n.s., licking). However, the licking response (Figure 1A), which is highly sensitive to analgesic agents and is considered an accurate measure of antinociceptive potency in rodents, showed a significantly reduced antinociceptive effect of acute administration of $10 \mathrm{mg} / \mathrm{kg}$ morphine in TgNTRK3 mice $\left(t_{(1,47)}=2.02\right.$, $p<0.05$, Student's $t$ test). Besides, no differences between genotypes were observed when using neither 2.5 nor $5 \mathrm{mg} / \mathrm{kg}$ of morphine 
$\left(t_{(1,20)}=0.04\right.$, n.s., and $t_{(1,18)}=-0.59$, n.s., respectively, Student's $t$ test $)$ in independent groups of mice. Regarding the jumping response, the higher doses of morphine ( 5 and $10 \mathrm{mg} / \mathrm{kg}$ ) showed a ceiling effect (Figure 1B). However, when using a dose of $2.5 \mathrm{mg} / \mathrm{kg}$ of morphine no significant differences were observed between genotypes $\left(t_{(1,20)}=0.18\right.$, n.s., Student's $t$ test $)$. In the tail immersion test (Figure 1C) no significant differences in the acute antinociceptive effects of morphine were observed between genotypes as reflected by a similar tail withdrawal latency $\left(t_{(1,48)}=0.66\right.$, n.s., Student's $t$ test $)$.

The analysis of locomotor activity revealed that the acute effect of morphine on locomotion was similar between genotypes $\left(F_{(1,107)}=0.81\right.$, n.s., two-way ANOVA, Figure 2A). An independent experiment measuring locomotor activity during longer time periods (during $60 \mathrm{~min}$ after morphine administration) also did not show differences between genotypes (Figure S1 in Supplementary Material)

\section{MORPHINE-INDUCED LOCOMOTOR SENSITIZATION AND DEVELOPMENT OF TOLERANCE TO MORPHINE ANTINOCICEPTION WERE NOT MODIFIED BY THE OVEREXPRESSION OF NTRK3}

We monitored the development of tolerance and sensitization over the course of 7 days, induced by daily injections of morphine (10 mg/kg twice-a-day). Locomotor activity was measured after saline or morphine injection during the first hours of the light phase (Figure 2A). Animals of either genotype were habituated to the activity cages during 2 days showing a reduction in total locomotor activity between the first and second day $\left(F_{(1,106)}=76.91, p<0.001\right.$, ANOVA repeated measures). The habituation to the apparatus was similar in both genotypes $\left(F_{(1,106)}=0.13\right.$, n.s., one-way ANOVA). Morphine administration along 7 days after habituation elicited sensitization to total locomotor activity in WT and TgNTRK3 mice when compared to saline groups $\left(F_{(7,97)}=3.02, p<0.01\right.$; ANOVA repeated measures) with no differences between genotypes $\left(F_{(7,97)}=0.04\right.$, n.s. two-way ANOVA). Moreover, no differences between genotypes were observed along the 7 days of treatment in neither morphine groups $\left(F_{(7,42)}=0.43\right.$, n.s., one-way ANOVA) or saline groups $\left(F_{(7,49)}=1.01\right.$, n.s., one-way ANOVA). Locomotor sensitization also was studied changing the administration protocol. In this experiments, when morphine $(10 \mathrm{mg} / \mathrm{kg})$ was administered only once every 2 days again no differences were observed between genotypes (Figure S1 in Supplementary Material).

Development of tolerance was studied measuring antinociception with the tail immersion test (Figure 2B). During the first 2 days mice of either genotype did not show differences in the habituation to the apparatus $\left(F_{(1,120)}=0.23\right.$, n.s., one-way ANOVA). Both TgNTRK3 and WT mice exhibited a progressive loss of morphine antinociceptive effect along sessions in the tail immersion test as reflected by no differences in the reduction of the \%MPE $\left(F_{(7,41)}=0.31\right.$, n.s., ANOVA repeated measures). Saline-treated mice also showed no genotype differences during the 8 days $\left(F_{(7,62)}=0.04\right.$, n.s., one-way ANOVA). Two-way ANOVA repeated measures revealed no interaction between treatment and genotype $\left(F_{(7,109)}=0.42\right.$, n.s. $)$ along days.

\section{NALOXONE-PRECIPITATED WITHDRAWAL SYNDROME AFTER INCREASING} DOSES OF MORPHINE WAS SIMILAR IN TgNTRK3 AND WT MICE

In the first experiment, withdrawal was induced after 6 days of progressively increasing doses of morphine with a subcutaneous injection of naloxone $2 \mathrm{~h}$ after the last morphine injection (Figure 3A).
Both WT and TgNTRK3 mice showed the characteristic signs of opiate withdrawal, including autonomic hyperactivity, wet dog shakes, paw tremor, piloerection, jumps, and other withdrawalrelated behaviors. No differences between genotypes were observed in the score obtained for each behavioral sign checked. The total withdrawal score was similar for the TgNTRK3 and WT mice $\left(F_{(1,79)}=0.82\right.$, n.s., two-way ANOVA $)$.

\section{NALOXONE-PRECIPITATED WITHDRAWAL SYNDROME WAS INCREASED AFTER BY CONSTANT DOSES OF MORPHINE IN TgNTRK3 MICE}

In order to discard a possible ceiling effect on withdrawal symptoms after dependence induced by increasing dose of morphine, we examined withdrawal symptoms after dependence induced by a lower constant dose of morphine $(20 \mathrm{mg} / \mathrm{kg}$ ) (Figure 3B). Two-way ANOVA revealed interaction between genotype and treatment $\left(F_{(1,41)}=5.99\right.$, $p<0.05)$. Student's $t$ test analysis revealed a significant increase in global symptoms score in TgNTRK3 as compared to WT mice $\left(t_{(1,16)}=-2.46\right.$, $p<0.05)$. No differences were observed in animals treated with saline plus naloxone $\left(t_{(1,21)}=-0.99\right.$, n.s., Student's $t$ test $)$.

\section{DECREASED ANXIETY BEHAVIOR OF TgNTRK3 MICE DURING WITHDRAWAL SYNDROME}

Anxiety was evaluated in the zero-maze test during morphine withdrawal (Figure 4). No interaction between genotype and treatment was revealed by two-way ANOVA in any of the quantified behaviors $\left(F_{(1,38)}=1.43\right.$, n.s., number of crossings; $F_{(1,39)}=1.46$, n.s., time spent in open arms; $F_{(1,38)}=0.62$, n.s., latency to open arms). However, TgNTRK3 mice showed a significant increase in time spent in open arms (Figure 4A) during morphine withdrawal when compared to saline-treated transgenic mice after naloxone injection $\left(t_{(1,19)}=-2.24, p<0.05\right.$, Student's $t$ test $)$. The latency to enter in open arms (Figure 4B) was lower during morphine withdrawal in both $\operatorname{TgNTRK} 3\left(t_{(1,19)}=2.83, p=0.01\right.$, Student's $t$ test $)$ and WT mice, although the latter did not reach significant differences $\left(t_{(1,19)}=1.13\right.$, n.s., Student's $t$ test).

\section{NT-3, BDNF AND THEIR RECEPTORS TrkC AND TrkB MRNAS LEVELS ARE DIFFERENTIALLY REGULATED AFTER CHRONIC MORPHINE ADMINISTRATION AND PRECIPITATED WITHDRAWAL IN TgNTRK3 MICE}

To test whether opiate-induced regulation of neurotrophin expression was modified in TgNTRK3 mice, coronal sections throughout the LC of saline-treated and morphine-treated mice were processed for in situ hybridization of NT-3, BDNF and TrkC, TrkB mRNAs (Figure 5; Table 1). Densitometric analysis of film autoradiograms confirmed the increased levels of TrkC mRNA that were previously reported in the LC (Dierssen et al., 2006) of TgNTRK3 after saline plus naloxone $\left(t_{(1,95)}=-2.66, p<0.01\right.$, Student's $t$ test $)$. These increased levels of TrkC mRNA were accompanied by an increase in NT-3 mRNA levels $\left(t_{(1,55)}=-3.53, p=0.001\right.$, Student's $t$ test $)$, thus confirming previous data observed at the protein level (Dierssen et al., 2006).

After both chronic morphine treatment, and precipitated withdrawal, NT-3 mRNA levels were not modified with respect to saline plus naloxone neither in WT $\left(F_{(2,82)}=2.12\right.$, n.s., one-way ANOVA) nor in TgNTRK3 $\left(F_{(2,70)}=1.06\right.$, n.s., one-way ANOVA). However, in chronic morphine-treated mice, the levels of NT-3 were significantly higher in TgNTRK3 than in WT mice $\left(_{(1,35)}=-3.17\right.$, 


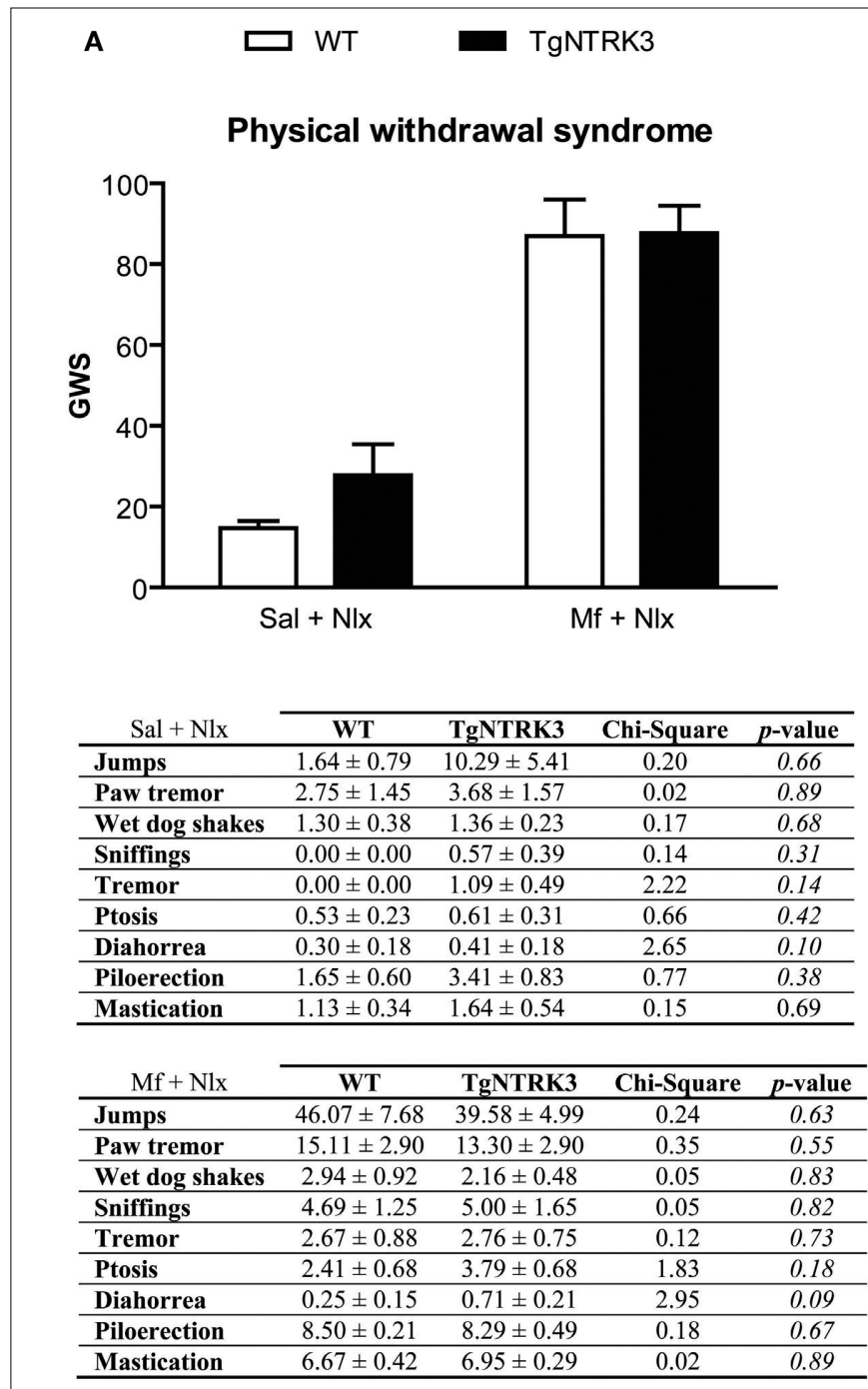

FIGURE 3 | Global withdrawal score after naloxone administration in morphine (Mf)-treated mice. Mice received chronic treatment with (A) increasing or (B) constant doses of morphine. Withdrawal was precipitated in both groups by the administration of the opioid receptor antagonist, naloxone (NIx, $1 \mathrm{mg} / \mathrm{kg}$, s.c.). Somatic signs of withdrawal were recorded during $45 \mathrm{~min}$,
B

\section{Physical withdrawal syndrome}

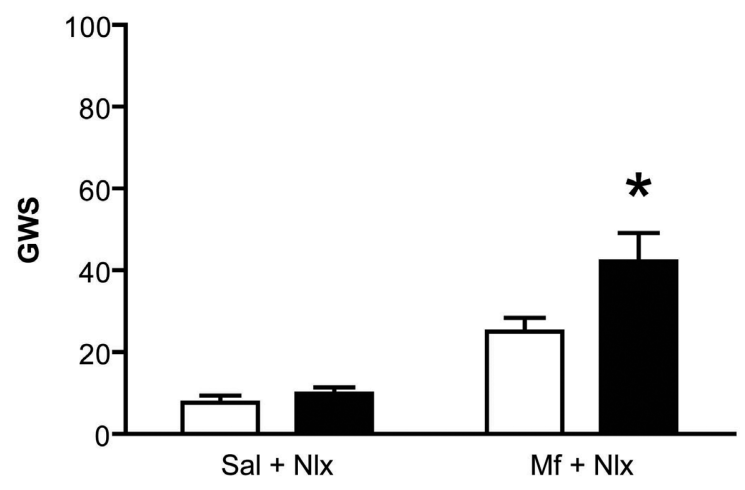

\begin{tabular}{lcccc}
\cline { 2 - 5 } Sal + Nlx & WT & TgNTRK3 & Chi-Square & $p$-value \\
\cline { 2 - 5 } Jumps & $0.12 \pm 0.12$ & $1.12 \pm 0.95$ & 0.81 & 0.37 \\
\hline Paw tremor & $0.75 \pm 0.28$ & $1.08 \pm 0.21$ & 1.84 & 0.17 \\
\hline Wet dog shakes & $0.54 \pm 0.24$ & $1.09 \pm 0.48$ & 6.52 & $0.01^{* *}$ \\
\hline Sniffings & $0.00 \pm 0.00$ & $0.00 \pm 0.00$ & 0.00 & 1.00 \\
\hline Tremor & $0.34 \pm 0.25$ & $0.30 \pm 0.20$ & 0.03 & 0.85 \\
\hline Ptosis & $0.69 \pm 0.32$ & $1.20 \pm 0.62$ & 0.12 & 0.73 \\
\hline Diahorrea & $0.00 \pm 0.00$ & $0.00 \pm 0.00$ & 0.00 & 1.00 \\
\hline Piloerection & $1.27 \pm 0.77$ & $0.00 \pm 0.00$ & 2.53 & 0.11 \\
\hline Mastication & $0.69 \pm 0.21$ & $0.30 \pm 0.20$ & 1.63 & 0.20 \\
\hline & & & & \\
\cline { 2 - 6 } Mf + Nlx & WT & TgNTRK3 & Chi-Square & $p$-value \\
\hline Jumps & $2.40 \pm 1.59$ & $9.68 \pm 2.44$ & 5.65 & $0.02^{*}$ \\
\hline Paw tremor & $3.23 \pm 1.34$ & $21.03 \pm 7.09$ & 7.29 & $0.00^{* * *}$ \\
\hline Wet dog shakes & $2.78 \pm 0.46$ & $5.00 \pm 1.49$ & 0.63 & 0.27 \\
\hline Sniffings & $0.83 \pm 0.83$ & $0.00 \pm 0.00$ & 1.11 & 0.29 \\
\hline Tremor & $0.83 \pm 0.36$ & $0.75 \pm 0.60$ & 0.89 & 0.34 \\
\hline Ptosis & $2.16 \pm 0.71$ & $0.60 \pm 0.46$ & 2.76 & 0.09 \\
\hline Diahorrea & $0.33 \pm 0.22$ & $060 \pm 0.24$ & 0.66 & 0.42 \\
\hline Piloerection & $1.17 \pm 0.99$ & $0.60 \pm 0.60$ & 0.50 & 0.48 \\
\hline Mastication & $2.83 \pm 0.48$ & $2.25 \pm 0.81$ & 0.78 & 0.37 \\
\hline
\end{tabular}

immediately after naloxone administration. The global withdrawal score was calculated for each animal by giving a relative weight to each withdrawal sign (see Materials and Methods). Data are expressed as means \pm SEM. Sal: Control saline-treated animals. Tables represent the scores of the physical withdrawal symptoms. $p<0.01$, Student's $t$ test) but after precipitated withdrawal, no genotype-dependent differences were observed $\left(t_{(1,58)}=-0.58\right.$, n.s., Student's $t$ test). TrkC mRNA levels showed a decrease after both chronic morphine treatment and precipitated withdrawal, in $\operatorname{TgNTRK} 3\left(F_{(2,102)}=12.34, p<0.001\right.$, one-way ANOVA $)$ but not in WT mice $\left(F_{(2,127)}=0.51\right.$, n.s., one-way ANOVA). Bonferroni post hoc analysis in TgNTRK3 mice revealed significant differences respect to saline plus naloxone $(p<0.001)$, but not respect to chronic morphine treatment.

In contrast to the increase of TrkC mRNA levels observed in TgNTRK3 mice under saline plus naloxone conditions, TrkB mRNA levels were reduced as compared to WT mice $\left(t_{(1,53)}=4.70\right.$, $p<0.001$, Student's $t$ test), but no differences in BDNF mRNA levels were observed between genotypes $\left(t_{(1,37)}=1.53\right.$, n.s., Student's $t$ test). TrkB mRNA expression levels were similarly reduced after chronic morphine administration showing no differences between genotypes $\left(t_{(1,39)}=1.05\right.$, n.s., Student's $t$ test $)$ but a significantly greater decrease was observed in TgNTRK3 mice after precipitated withdrawal $\left(t_{(1,65)}=2.05, p<0.05\right.$, Student's $t$ test $)$. However, whereas the reduction in TrkB levels with respect to saline-treated mice was significant in WT mice $\left(F_{(2,80)}=11.00, p<0.001\right.$; oneway ANOVA), TgNTRK3 mice showed no differences in mRNA TrkB expression among treatment groups $\left(F_{(2,81)}=1.02\right.$, n.s. oneway ANOVA). Bonferroni post hoc analysis revealed significant differences between saline and chronic morphine $(p<0.001)$ and also between saline and morphine withdrawal $(p<0.001)$ TgNTRK3 mice. The expression levels of BDNF changed after chronic morphine treatment and precipitated withdrawal in both WT $\left(F_{(2,73)}=5.51, p<0.001\right.$, one-way ANOVA $)$ and TgNTRK3 mice $\left(F_{(2,68)}=9.59, P<0.001\right.$, one-way ANOVA $)$, but a Bonferroni 

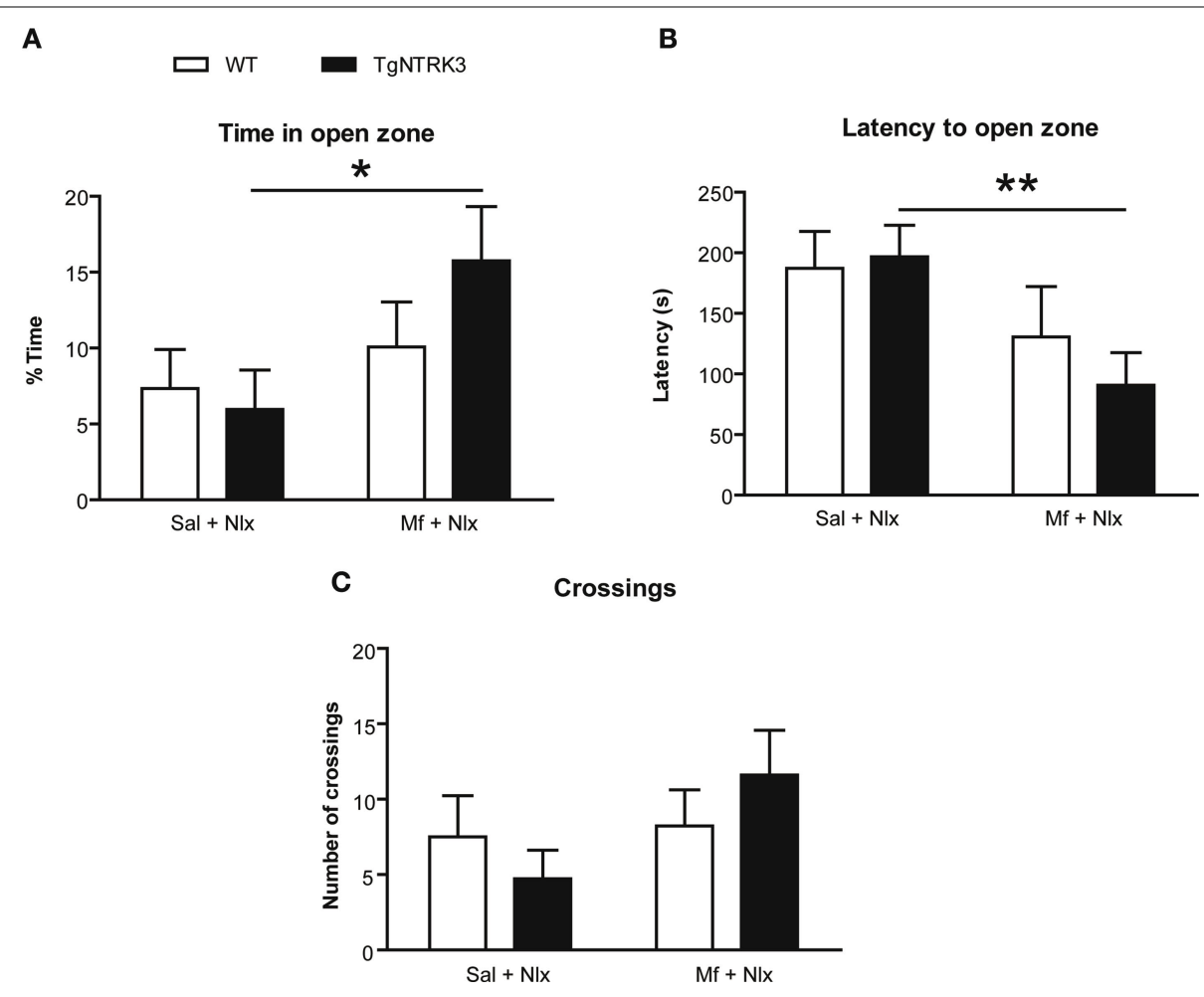

FIGURE 4 | Zero-maze test during withdrawal syndrome. The anxiogenic effects of morphine withdrawal were studied using the zero-maze test immediately after evaluation of withdrawal symptoms in animals receiving constant doses of morphine (20 mg/kg). (A) Time spent in open zone. (B) Latency to enter the open zone. (C) Number of crossings. Data are expressed as means \pm SEM. ${ }^{*} p<0.05,{ }^{*} p<0.01$. post hoc test showed significant differences only in TgNTRK3 but not in WT mice when comparing chronic morphine treatment vs. saline $(p<0.001)$. However, significant differences were observed in both genotypes when comparing precipitated withdrawal vs. saline ( $p<0.01$ in WT and $p<0.001$ in TgNTRK3 mice).

To test whether the mRNA expression observed in the in situ hybridization was due to altered mRNA expression of endogenous TrkC in LC, we used Lightcycler qRT-PCR analysis. Data showed no differences in mRNA expression in brainstem of TgNTRK3 mice (Table 2) using probes to discriminate between mouse and human receptors. The statistical analysis showed no significant differences in endogenous TrkC FL $(1.01 \pm 0.33, p=0.93$, n.s. $)$ and Trkc TF $(1.00 \pm 0.25, p=0.91$, n.s. $)$ expression of TgNTRK 3 mice with respect to WT.

\section{NTRK3 OVEREXPRESSION ALTERS NORADRENERGIC NEURONAL ACTIVITY AND OCCLUDES MORPHINE-INDUCED FUNCTIONAL ADAPTATIONS IN THE LC}

An elevated activity of LC neurons has been postulated to contribute to the expression of opiate withdrawal in morphine-dependent rats (Kogan et al., 1992). To examine whether the TrkC receptor regulates this withdrawal-induced hyperactivity, single-unit extracellular recordings of LC neurons were obtained in brain slices from WT and TgNTRK3 mice. Spontaneous firing rates were recorded during in vitro opioid withdrawal in a total of 192 LC cells (on average, 6 cells/slice) from mice chronically treated with morphine or saline. After saline treatment, firing rate values of LC neurons in WT animals $(0.75 \pm 0.1, n=8)$ were within the range previously reported in rat brain slices (Kogan et al., 1992). In vitro opiate withdrawal in morphine-treated WT mice increased the firing rates of LC cells $(+73 \%, n=8, p<0.05)$ compared to the values in the corresponding saline-treated group (Table 3; Figure 6A). The magnitude of this increase was similar to that previously reported in slices from morphine-dependent mice (Martin et al., 2003). Paradoxically, although firing rates in TgNTRK3 after saline treatment were significantly elevated with respect to WT $(1.28 \pm 0.1 \mathrm{~Hz}$, $n=8 ; p<0.05$ ) (Table 3; Figure 6A), they were not significantly elevated during opiate withdrawal $(n=8)$ with respect to WT or saline-treated groups (Table 3; Figure 6A), suggesting that $\mathrm{TrkC}$ receptor overexpression is able to mimic and thereby occlude morphine-induced functional adaptations in the LC. The possibility of residual morphine present in the slice from dependent animals was explored by the administration of naloxone immediately after the cell sampling: naloxone $(1 \mu \mathrm{M})$ failed to change the firing rate of LC cells in either group (data not shown).

To further characterize the changes found in the LC from mice overexpressing TrkC, we tested the functionality of $\mu$-opioid receptors by constructing concentration-effect curves for ME in chronically morphine- and saline-treated mice. In WT mice, treatment with increasing doses of morphine induced a moderate degree of opioid tolerance in the LC, as revealed by a rightward shift in the concentration-effect curves (Figure 6B) and a 4-fold increase in the $\mathrm{EC}_{50}$ for $\mathrm{ME}(n=9)$ compared to the saline group ( $n=8$; One-way ANOVA, $\mathrm{F}(3,25)=3.16$; post hoc, $p<0.05$; Table 3 ). Interestingly, 
A WT

TgNTRK3
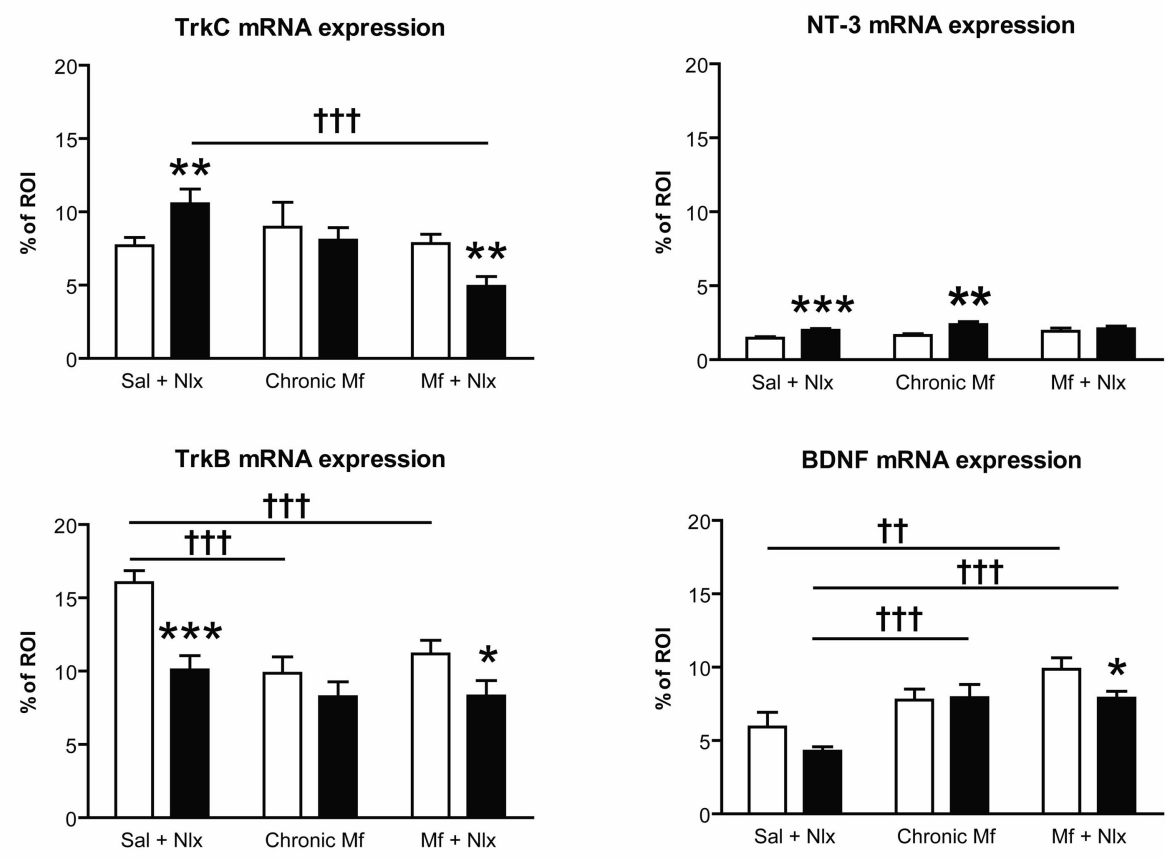

B
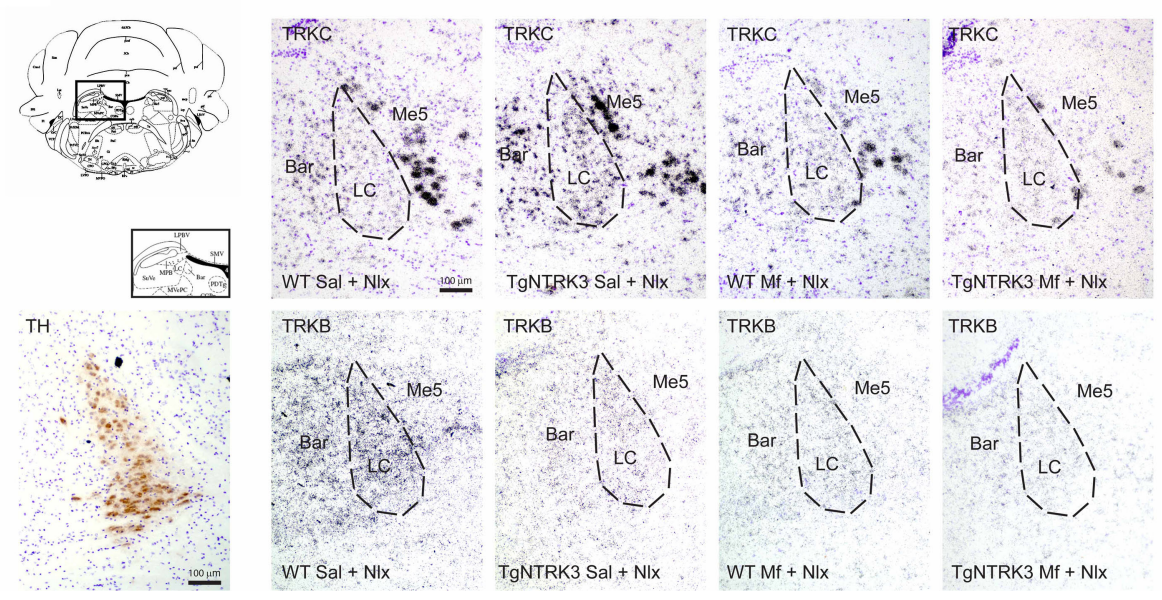

TRKB

TRKB
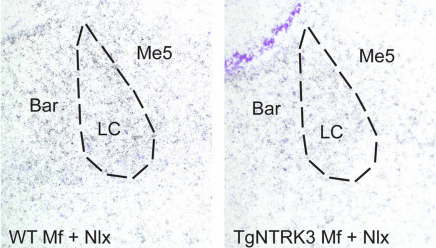

FIGURE 5 | In situ hybridization of TrkC, TrkB and their ligands after chronic morphine administration and precipitated withdrawal. (A) Expression of TrkC, NT-3, TrkB and BDNF given as percentage of intensity for the region of interest (\% of ROI) in WT (white bars) andTgNTRK3 (black bars) mice. (B) Diagram showing the locus coeruleus (LC) localization and photomicrographs of consecutive $14 \mu \mathrm{m}$ coronal sections labeled with TH antibody (1:8000; Sigma, MO, USA) served to define the LC counting area (left-lower panel). Photomicrographs of $14 \mu \mathrm{m}$ coronal sections (right-lower panel) illustrate TrkC and TrkB expression in the LC of WT and TgNTRK3 mice. Data are expressed as means \pm SEM. ${ }^{*} p<0.05,{ }^{*} p<0.01$, ${ }^{* *} p<0.005$ when compared with the corresponding WT group (Student's $t$ test), and $+p<0.05$, $\uparrow+p<0.01$, $\uparrow+\uparrow p<0.005$ when compared with the corresponding saline group (Student's $t$ test). the $\mathrm{EC}_{50}$ value obtained from concentration-effect curves for $\mathrm{ME}$ in saline-treated TgNTRK3 mice was also significantly shifted to the right $(n=4, p<0.05)$ compared to that in the corresponding WT group ( $n=8$; Table 3 ). However, after chronic treatment with morphine in TgNTRK3 mice no further change was observed in the $\mathrm{EC}_{50}$ value for $\mathrm{ME}(n=8)$ as compared to the corresponding curve in saline-treated mice (Table 3). In fact, concentration-effect curves in morphine-treated TgNTRK 3 mice were not different from those in morphine-treated WT mice (Figure 6B; Table 3), confirming that $\mathrm{TrkC}$ receptor overexpression occludes morphine-induced functional adaptations in the LC.

\section{DISCUSSION}

In the present work, constitutive TrkC overexpression in a model of panic disorder, TgNTRK3 mice (Dierssen et al., 2006), dramatically alters spontaneous firing rates of LC neurons and the 
Table 1 | In situ hybdridization of TrkC, TrkB and their ligands after chronic morphine administration and precipitated withdrawal.

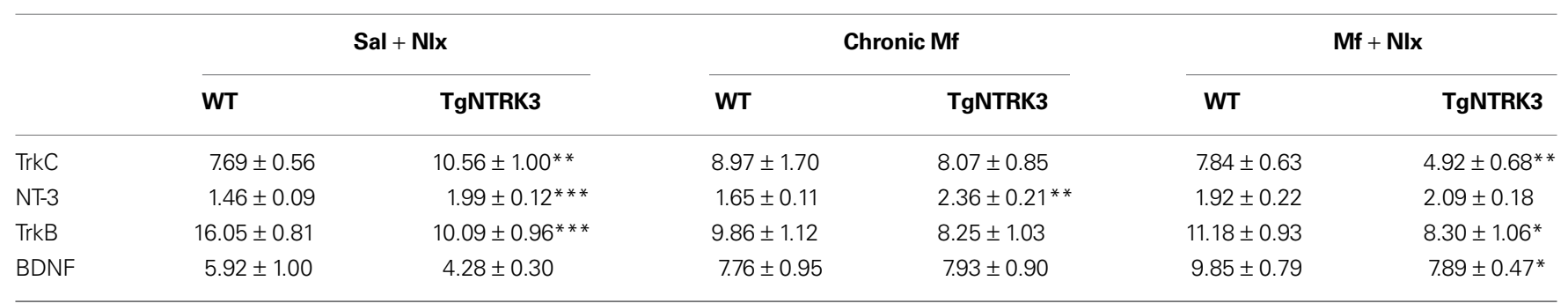

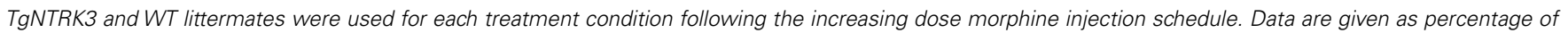
intensity for the region of interest (\% of ROI) \pm SEM. ${ }^{*} p<0.05,{ }^{*} p<0.01,{ }^{* * *} p<0.001$ (Student's $t$ test, WT vs. TgNTRK3 mice).

Table 2 | Quantitative RT-PCR analysis of TrkC full-length isoform (FL) and TrkC truncated isoform (TF).

\begin{tabular}{lllll}
\hline Gene & Fold-Change* & Std. error & p-value & Sig. \\
\hline TrkC FL & 1.01 & 0.33 & 0.93 & n.s. \\
TrkCTF & 1.00 & 0.25 & 0.91 & n.s.
\end{tabular}

Fold-change*: Endogenous TrkC receptor expression in TgNTRK3 with respect to WT mice. Pair Wise Reallocation Randomisation Test@ (Relative Expression Software Tool - 384 (REST-384C v.2).

response of the noradrenergic system to chronic opiate exposure, possibly related to the paradoxical regulation of neurotrophic peptides observed in this model. Notably, TgNTRK3 LC neurons showed an increased firing rate in saline-treated conditions and profound abnormalities in their response to ME. In contrast, the behavioral withdrawal pattern was not modified, nor were either the development of tolerance or the locomotor sensitization to morphine when it was administered at increasing doses. Conversely, chronic constant doses of morphine induced a significantly increased behavioral withdrawal syndrome in TgNTRK3.

LC is involved in the pathogenesis of panic disorder (Protopopescu et al., 2006) and has served as a model system for the pharmacology and cellular basis of opiate tolerance, dependence, and withdrawal (Nestler and Aghajanian, 1997). Several studies have suggested that panic attacks might be the consequence of hyperactivity of LC noradrenergic cells (David Johnson, 2003; Valenca et al., 2004) and changes in the expression of neurotrophins and their receptors are essential for opiate-induced adaptations (Numan et al., 1998; Akbarian et al., 2001, 2002; Hatami et al., 2007). In the present work we observed profound abnormalities in LC neuronal responses in basal conditions and after chronic opiate exposure in TgNTRK3 mice. Spontaneous LC neurons basal firing rates of TgNTRK3 mice were abnormally elevated with respect to WTs. These neurons possess $\mu$-opioid receptors and are innervated by enkephalin and endorphin fibers (Strahlendorf et al., 1980; Drolet et al., 1992). Similarly, exogenous opioid agonists, acting at $\mu$ receptors, produce inhibition of LC cells, a pharmacological inhibition reversed by opioid antagonists such as naloxone, which in turn induces hyperactivity of noradrenergic cells. The nucleus paragigantocellularis (Ennis and Aston-Jones, 1988), which has been implicated in the hyperactivity of LC neurons during withdrawal, is an important source of NT-3 and BDNF (Rasmussen and Aghajanian, 1989) to the LC.
In fact, deregulation of the brainstem opioid system may underlie critical aspects of panic disorder neurobiology, since clinical studies show that normal subjects experience strong physiological reactivity to naloxone-lactate (Sinha et al., 2007) although other studies (Liebowitz et al., 1984) found that panic patients' response to lactate infusion was not modulated by naloxone pretreatment. This lack of effect of naloxone in panic patients has been interpreted as a tonic or phasic opioid hypofunction, although in some cases panic attacks can be precipitated by the administration of naltrexone in a subgroup of panic disorder patients (Maremmani et al., 1998). We tested the functionality of $\mu$-opioid receptors in the LC of TgNTRK3 mice, by constructing concentration-effect curves for ME in chronically morphine- and saline-treated mice. Interestingly, the $\mathrm{EC}_{50}$ value for ME in saline-treated TgNTRK3 mice was significantly increased compared to the corresponding WT group. These results suggest that overexpression of TrkC leads to hypofunction of opioid receptors, and to a reduced endogenous inhibitory control of LC neurons. Consistently with these results, TgNTRK3 mice present a significantly reduced acute antinociceptive effect of morphine.

It could be argued that an increased excitatory afferent input to the LC could contribute to disinhibition of noradrenergic neurons (Williams and North, 1984; Akaoka and Aston-Jones, 1991; Aghajanian et al., 1994). However, in our experiments, given the fact that the recordings were conducted on coronal slice preparations that disrupt afferent inputs of the LC, it is unlikely that the observed increase in LC neuronal firing in the mutants is caused by an imbalance between GABAergic and glutamatergic excitatory signal transmission (Van Bockstaele et al., 2000) to the LC. In fact, in WT mice, treatment with morphine induced a rightward shift in the concentration-effect curves for ME that revealed a moderate degree of opioid tolerance, but no change was observed in the ME $\mathrm{EC}_{50}$ in TgNTRK3 mice. Thus, we monitored the development of tolerance and sensitization over the course of several days, and we observed that both TgNTRK3 and control mice developed a similar change in morphine responsiveness, indicating that neither tolerance nor sensitization were affected by $\operatorname{TrkC}$ overexpression. It is tempting to suggest that $\operatorname{TrkC}$ receptor overexpression is able to mimic and thereby occlude morphine-induced functional adaptations in the LC, suggesting that overexpression of TrkC could be a mechanism in the noradrenergic plasticity in LC (Akbarian et al., 2001, 2002). 
Table 3 | Effect of morphine on the spontaneous firing rate and on the inhibition induced by ME in LC neurons from WT and TgNTRK3 mice.

\begin{tabular}{|c|c|c|c|c|c|c|c|}
\hline \multirow[b]{2}{*}{ Treatment groups ${ }^{1}$} & & \multirow[b]{2}{*}{ Firing rate $(\mathrm{Hz})$} & \multicolumn{5}{|c|}{ Concentration-effect curves ${ }^{2}$} \\
\hline & & & $n$ & $\log \mathrm{EC}_{50}$ & $\left(\mathrm{EC}_{50} \mu \mathrm{M}\right)$ & Slope factor & $n$ \\
\hline Saline & TgNTRK3 & $12.78 \pm 1.30^{+}$ & 8 & $-5.44 \pm 0.28 *$ & (3.62) & $0.74 \pm 0.11$ & 4 \\
\hline \multirow[t]{2}{*}{ Morphine } & WT & $12.34 \pm 1.40^{*}$ & 8 & $-5.56 \pm 0.13^{\dagger}$ & $(2.74)$ & $1.11 \pm 0.32$ & 9 \\
\hline & TgNTRK3 & $10.86 \pm 1.11$ & 8 & $-5.62 \pm 0.10$ & (2.38) & $0.92 \pm 0.06$ & 8 \\
\hline
\end{tabular}

${ }^{1}$ Animals were treated chronically with saline or morphine for 5 days. Recordings were performed $1.5 \mathrm{~h}$ after slice preparation to allow morphine to wash out.

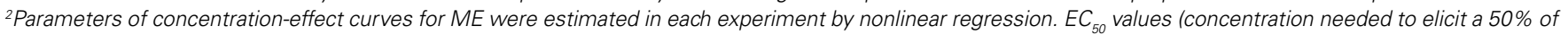

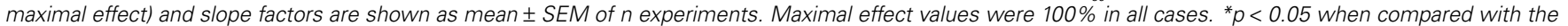
corresponding WT group; ${ }^{\dagger} p<0.05$ when compared with the corresponding saline group (one-way ANOVA followed by a post hoc Student's or Tukey's $t$ test).

Regarding opioid withdrawal, electrophysiological studies have shown that after chronic morphine treatment, naloxone-induced withdrawal triggers intense hyperactivity of LC neurons that is prevented by clonidine treatment (Taylor et al., 1988; Kogan et al., 1992). In our experiments, LC cells from WT mice chronically treated with morphine showed the typical hyperactivation during in vitro withdrawal. However, this elevation of firing rates during opioid withdrawal was not observed in TgNTRK3 mice, thus suggesting that the neuronal adaptations that take place during chronic morphine treatment had not been produced in TgNTRK3 mice. Since an increase in LC activity has been argued to be both necessary and sufficient to induce most opiate withdrawal behaviors (Grant et al., 1988; Maldonado and Koob, 1993; Nestler and Aghajanian, 1997), the fact that the LC firing rate was not further increased by morphine withdrawal in TgNTRK3 mice would be in accordance with previous studies showing that lesions affecting the LC do not abolish opiate withdrawal reactions (Christie et al., 1997; Caille et al., 1999; Delfs et al., 2000). Thus, we decided to investigate the behavioral withdrawal syndrome. Using increasing doses of morphine, we did not observe qualitative or quantitative differences in somatic or behavioral withdrawal signs between WT and TgNTRK3 animals. In fact, the spontaneous firing rates of LC neurons of morphine-treated mice using the same dosage regime were not different between both genotypes. However, it has been argued that decreasing the dose or duration of morphine administration can reduce drug's withdrawal behavioral symptoms thus increasing the sensitivity of the assay (Haghparast et al., 2008). In fact, in TgNTRK3 mice constant low doses of morphine induced a significantly more intense behavioral withdrawal syndrome. This suggests that a ceiling effect may have been reached in the previous experiment, and that the appearance of adverse effects may have hidden the real withdrawal signs. This ceiling effect may be explained either by an opposing effect of down-regulated TrkC in TgNTRK 3 mice treated with increasing doses of morphine (see Figure 5A) or by the fact that LC neurons from TgNTRK3 mice are more resistant to opioid inhibition (see Figure 6), which would attenuate induction of spontaneous hyperactivity during morphine withdrawal as shown by Cruz et al. (2008). Alternatively, other structures than the LC that are regulated by morphine may participate in opiate withdrawal. Also, since withdrawal has been related to an increase in anxiety in humans and mouse models (Schulteis et al., 1998), we tested the possible anxiogenic effects of withdrawal in our panic disorder mouse model. Surprisingly, in our experiments using the zero-maze test we could not detect an increase in anxiety-like behaviors in either WT or TgNTRK3. Conversely both genotypes spent more time in the aversive zones but this reduced anxiety levels were more clear in TgNTRK 3 mice. This supports the possibility that zero-maze test behaviors might not be driven exclusively by anxiety levels but rather by other withdrawal-induced behaviors, as has been reported using the elevated plus maze (Hodgson et al., 2008; Buckman et al., 2009).

Increased TH expression and catalytic activity (Guitart et al., 1990; Lane-Ladd et al., 1997; Boundy et al., 1998) in the LC is considered a key element in the neuroadaptations produced by chronic morphine administration has been shown to. This upregulation of TH would be expected to increase the capacity of noradrenergic neurons to synthesize norepinephrine, which then could contribute to the dramatic increase in norepinephrine release and to behavioral changes described during opiate withdrawal (Koob, 1992; Grasing et al., 1997). In TgNTRK3 mice, we previously described an up-regulation of $\mathrm{TH}$ that may be due to the increased cell numbers in LC (Dierssen et al., 2006). Therefore, one would predict that the TH upregulation in the LC of TgNTRK3 mice would contribute to the increased basal LC activity, observed in the present work.

In our model, it was also relevant to establish the possible modifications in neurotrophin expression, since the NT-3/TrkC system has been suggested to interfere with the biological effects of opiates through direct effects on noradrenergic neurons. NT-3 opposes, in vitro, the decline in embryonic A6 neuron numbers after chronic morphine exposure (Sklair-Tavron and Nestler, 1995) and mice with a CNS-wide deletion of NT-3 had attenuated withdrawal reactions that were restored by transgene-derived overexpression of NT-3 in noradrenergic neurons (Akbarian et al., 2001). In TgNTRK3 mice the LC phenotype could thus emanate from the alteration of both BDNF and NT-3 systems. Interestingly, neurotrophins can recover a noradrenergic phenotype in 'resting noradrenergic' neurons in the adult LC (Bezin et al., 2000), a mechanism that could be involved in the pathological alteration of LC in psychiatric conditions such as panic disorder or substance abuse. Chronic opiate treatment and 


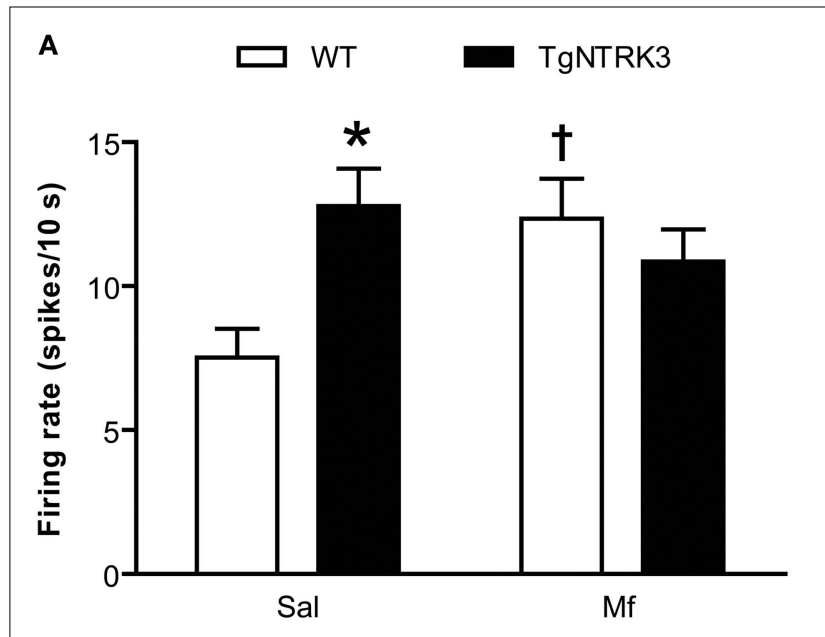

B

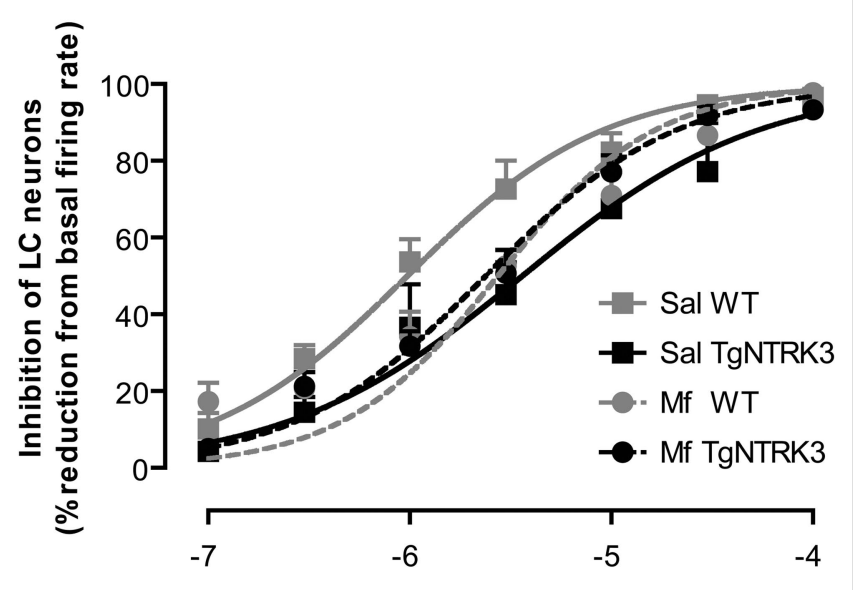

FIGURE 6 | Effect of morphine withdrawal on spontaneous firing rate of LC neurons and concentration-effect curves for met-enkephalin (ME)-induced inhibition. (A) To assess whether physical withdrawal signs of TgNTRK3 mice were paralleled at the cellular level by increased activities of $\mathrm{LC}$ neurons, we recorded the firing rates of these neurons in slices from WT (black bars) and TgNTRK3 animals (white bars) treated with saline or morphine. Single-unit extracellular recordings were performed $2 \mathrm{~h}$ after slices preparation to allow morphine to wash out. Bars represent the mean \pm SEM. ${ }^{*} p<0.05$ when compared with the corresponding WT group; $\dagger p<0.05$ when compared with the corresponding saline group (one-way ANOVA followed by a Tukey's multiple comparison $t$ test). (B) Concentrationeffect curves were constructed for the inhibitory effect of the $\mu$-opioid receptor agonist $\mathrm{ME}$ on the $\mathrm{LC}$, by adding increasing concentrations of the drug $(0.1-100 \mu \mathrm{M}, 3.3 \times)$ at 5-min intervals until a maximal effect was reached. The horizontal axis represents the logarithmic value of $\mathrm{ME}$ concentrations. The vertical axis expresses the percentage of reduction in the firing rate from the basal rate. Data are mean \pm SEM. at each $M E$ concentration. The lines are the theoretical curves in each group constructed from the mean of the individual concentration-effect curve parameters, as estimated by nonlinear regressions (see Materials and Methods for details and Table $\mathbf{3}$ for mean values). In all groups, the maximal effect of ME was $100 \%$ of baseline.

withdrawal differentially regulate neurotrophin and their receptor mRNAs in catecholaminergic nuclei (Seroogy et al., 1994; Hung and Lee, 1996; Numan et al., 1998; Numan and Seroogy, 1999). Concretely, both BDNF/TrkB and NT-3/TrkC systems have been proposed to regulate the neurochemical adaptations of the noradrenergic system in response to opiate exposure (Numan et al., 1998; Akbarian et al., 2001, 2002). It has been shown (Numan et al., 1998), that chronic morphine exposure resulted in modest increases in BDNF and NT-3 but unchanged TrkB or TrkC mRNA expression in LC, while precipitated withdrawal leads to a marked, rapid, and prolonged increase in BDNF mRNA, a delayed decrease in NT-3 mRNA, and to an elevation of both TrkB and TrkC mRNAs at 2 and $6 \mathrm{~h}$ of withdrawal in the rat. In our experiments, chronic morphine treatment led to small changes in NT-3 and BDNF mRNA levels and precipitated opiate withdrawal resulted in a robust increase in BDNF along with a slight decrease in NT-3 mRNA levels in WT mice. However, in contrast to previous observations, TrkC was not modified after chronic morphine treatment, but a robust decrease in TrkB expression was observed in WT mice. In TgNTRK3 mice we observed a different regulation of NT-3, BDNF and their receptors TrkC and TrkB mRNA after chronic morphine administration and precipitated withdrawal. These data suggest that variable combinations and intensities of neurotrophin-signaling pathways in neuronal circuits that are interconnected with noradrenergic neurons could adjust and fine-tune opiate-related adaptations of the noradrenergic system.

In conclusion, we show here that the NT-3/TrkC is an important regulator of neuronal firing in LC and would contribute to the adaptations of the noradrenergic system in response to chronic opiate exposure. These results may explain the perturbation of naloxone response in panic disorder patients and naltrexoneinduced panic attacks (Arntz et al., 1993; Maremmani et al., 1998; Sinha et al., 2007). It remains to be elucidated whether the molecular mechanisms that mediate NT-3/TrkC neuronal plasticity in the noradrenergic system beyond these opiate-induced adaptations resemble those that operate in the hippocampus, where the overexpression of TrkC markedly increases synaptic activity and LTP (Sahún et al., 2007a). We propose that TrkC may act as a putative genetic interface for the co-occurrence of panic disorder and substance abuse.

\section{SUPPLEMENTARY MATERIAL}

The Supplementary Material for this article can be found online at http://www.frontiersin.org/behavioralneuroscience/paper/10.3389. neuro.08/060.2009/

\section{ACKNOWLEDGMENTS}

This work was funded by the Spanish Ministry of Education and Sciences SAF2007-31093-E, SAF2007-60827, and SAF200803612, 2009SGR1313 and Health (PI082038), Fundación Areces, Marató TV3, Phecomp (EU LSHM-CT-2007-037669; 037627AnEUploidy), Ministerio de Salud y Consumo (RTA G03/005 and PI05/0513, PI082038), University of the Basque Country (1/UPV 0026.327-E-15924/2004 and GIU07/46), Plan Nacional sobre Drogas (PNDMSC 2005) and CIBERER. Patricia Murtra is a scientific researcher supported by the Juan de la Cierva program of Ministerio de Ciencia y Tecnología. Teresa Zamalloa was supported by a predoctoral fellowship from the Basque Government. We thank John Crabbe for his comments and suggestions about the manuscript. 


\section{REFERENCES}

Aghajanian, G.K.(1978). Tolerance of locus coeruleus neurones to morphine and suppression of withdrawal response by clonidine. Nature 276, 186-188.

Aghajanian, G. K., Kogan, J. H., and Moghaddam, B. (1994). Opiate withdrawal increases glutamate and aspartate efflux in the locus coeruleus: an in vivo microdialysis study. Brain Res. 636, 126-130.

Aghajanian, G. K., and Wang, Y.Y. (1986). Pertussis toxin blocks the outward currents evoked by opiate and alpha 2-agonists in locus coeruleus neurons. Brain Res. 371, 390-394.

Akaoka, H., and Aston-Jones, G. (1991). Opiate withdrawal-induced hyperactivity of locus coeruleus neurons is substantially mediated by augmented excitatory amino acid input. J. Neurosci. 11, 3830-3839.

Akbarian, S., Bates, B., Liu, R. J., Skirboll, S. L.,Pejchal, T., Coppola,V.,Sun,L.D., Fan, G., Kucera, J., Wilson, M. A., Tessarollo, L., Kosofsky, B. E., Taylor,J. R., Bothwell, M., Nestler, E. J., Aghajanian, G. K., and Jaenisch, R. (2001). Neurotrophin3 modulates noradrenergic neuron function and opiate withdrawal. $\mathrm{Mol}$. Psychiatry 6, 593-604.

Akbarian, S., Rios, M., Liu, R. J., Gold, S. J., Fong, H. F., Zeiler, S., Coppola, V., Tessarollo, L., Jones, K. R., Nestler, E. J., Aghajanian, G. K., and Jaenisch, R. (2002). Brain-derived neurotrophic factor is essential for opiate-induced plasticity of noradrenergic neurons. J. Neurosci. 22, 4153-4162.

Arntz, A., Merckelbach, H., and de Jong, P. (1993). Opioid antagonist affects behavioral effects of exposure in vivo. J. Consult. Clin. Psychol. 61, 865-870.

Berhow,M.T., Russell,D.S., Terwilliger,R.Z., Beitner-Johnson, D., Self, D.W., Lindsay, R. M., and Nestler, E. J. (1995). Influence of neurotrophic factors on morphineand cocaine-induced biochemical changes in the mesolimbic dopamine system. Neuroscience 68, 969-979.

Bezin, L., Marcel, D., Desgeorges, S., Pujol, J. F., and Weissmann, D. (2000). Singular subsets of locus coeruleus neurons may recover tyrosine hydroxylase phenotype transiently expressed during development. Brain Res. Mol. Brain Res. 76, 275-281.

Binder, D. K., and Scharfman, H. E. (2004). Brain-derived neurotrophic factor. Growth Factors 22, 123-131.

Boundy, V. A., Gold, S. J., Messer, C. J. Chen, J., Son, J. H., Joh, T. H., and Nestler, E. J. (1998). Regulation of tyrosine hydroxylase promoter activity by chronic morphine in TH9.0LacZ transgenic mice. J. Neurosci. 18, 9989-9995.

Breslau, N., Davis, G. C., and Schultz, L. R. (2003). Posttraumatic stress disorder and the incidence of nicotine, alcohol, and other drug disorders in persons who have experienced trauma. Arch. Gen. Psychiatry 60, 289-294.

Buckman, S. G., Hodgson, S. R., Hofford, R. S., and Eitan, S. (2009). Increased elevated plus maze open-arm time in mice during spontaneous morphine withdrawal. Behav. Brain Res. 197, 454-456.

Caille, S., Espejo, E. F., Reneric, J. P., Cador, M., Koob, G. F., and Stinus, L. (1999). Totalneurochemicallesion of noradrenergic neurons of the locus ceruleus does not alter either naloxone-precipitated or spontaneous opiate withdrawal nor does it influence ability of clonidine to reverse opiate withdrawal. J. Pharmacol. Exp. Ther. 290, 881-892.

Chao, M. V. (2003). Neurotrophins and their receptors: a convergence point for many signalling pathways. Nat. Rev. Neurosci. 4, 299-309.

Chao, M. V., Rajagopal, R., and Lee, F. S. (2006). Neurotrophin signalling in health and disease. Clin. Sci. 110, 167-173.

Christie, M. J., Williams, J. T., Osborne, P. B., and Bellchambers, C. E. (1997) Where is the locus in opioid withdrawal? Trends Pharmacol. Sci. 18 134-140.

Cottler, L. B., Compton, W. M. III, Mager, D., Spitznagel, E. L., and Janca, A. (1992). Posttraumatic stress disorder among substance users from the general population. Am. J. Psychiatry 149 , 664-670.

Cruz, H. G., Berton, F., Sollini, M., Blanchet, C., Pravetoni, M., Wickman, K., and Luscher, C. (2008). Absence and rescue of morphine withdrawal in GIRK/Kir3 knock-out mice. J. Neurosci. 28, 4069-4077.

David Johnson, J. (2003). Noradrenergic control of cognition: global attenuation and an interrupt function. Med. Hypotheses 60, 689-692.

Dechant, G. and Barde, Y. A. (2002). The neurotrophin receptor $\mathrm{p} 75(\mathrm{NTR})$ : novel functions and implications for diseases of the nervous system. Nat. Neurosci. 5, 1131-1136.

Delfs, J. M., Zhu, Y., Druhan, J. P., and Aston-Jones, G. (2000). Noradrenaline in the ventral forebrain is critical for opiate withdrawal-induced aversion. Nature 403, 430-434

Dierssen, M., Florez, J., and Hurle, M. A. (1990). Calcium channel modulation by dihydropyridines modifies sufentanil-induced antinociception in acute and tolerant conditions. Naunyn Schmiedebergs Arch. Pharmacol. 342, 559-565.

Dierssen, M., Gratacos, M., Sahun, I., Martin, M., Gallego, X., AmadorArjona, A., Martinez de Lagran, M., Murtra, P., Marti, E., Pujana, M. A.
Ferrer, I., Dalfo, E., Martinez-Cue, C., Florez, J., Torres-Peraza, J. F., Alberch, J., Maldonado, R., Fillat, C. and Estivill, X. (2006). Transgenic mice overexpressing the full-length neurotrophin receptor TrkC exhibi increased catecholaminergic neuron density in specific brain areas and increased anxiety-like behavior and panic reaction. Neurobiol. Dis. 24 403-418.

Drolet, G., Van Bockstaele, E. J., and Aston-Jones, G. (1992). Robust enkephalin innervation of the locus coeruleus from the rostral medulla. $J$ Neurosci. 12, 3162-3174.

El-Kadi, A. O., and Sharif, S. I. (1997) The influence of chronic treatment with clonidine, yohimbine and idazoxan on morphine withdrawal. Psychopharmacology (Berl.) 132, 67-73.

Ennis, M., and Aston-Jones, G. (1988). Activation of locus coeruleus from nucleus paragigantocellularis: a new excitatory amino acid pathway in brain. J. Neurosci. 8, 3644-3657.

Florez, J., Dierssen, M., and Hurle, M. A (1990). Opiate analgesia and calcium channels modulation by dihydropyridines under acute and toleran conditions. Prog. Clin. Biol. Res. 328 461-464.

Friedman, W. J., Ibanez, C. F., Hallbook, F., Persson, H., Cain, L. D., Dreyfus, C. F., and Black, I. B. (1993). Differential actions of neurotrophins in the locus coeruleus and basal forebrain. Exp. Neurol. 119, 72-78.

Gear, R. W., Gordon, N. C., Heller, P. H., and Levine, J.D. (1995). Enhancement of morphine analgesia by the alpha 2-adrenergic antagonist yohimbine. Neuroscience 66, 5-8.

Grant, S. J., Huang, Y. H., and Redmond, D. E. Jr. (1988). Behavior of monkeys during opiate withdrawal and locus coeruleus stimulation. Pharmacol. Biochem. Behav. 30, 13-19.

Grasing, K., Bills, D., Ghosh, S. Schlussman, S. D., Patel, A. H., and Woodward, J. J. (1997). Opiate modulation of striatal dopamine and hippocampal norepinephrine release following morphine withdrawal Neurochem. Res. 22, 239-248.

Gratacos, M., Gonzalez, J. R., Mercader, J. M., de Cid, R., Urretavizcaya, M.,and Estivill, X. (2007). Brain-derived neurotrophic factor Val66Met and psychiatric disorders: meta-analysis of case-control studies confirm association to substance-related disorders, eating disorders, and schizophrenia. Biol. Psychiatry 61, 911-922.

Guitart, X., Hayward, M., Nisenbaum, L. K., Beitner-Johnson, D. B., Haycock, J. W., and Nestler, E. J. (1990). Identification of MARPP-58, a mor- phine- and cyclic AMP-regulated phosphoprotein of $58 \mathrm{kDa}$, as tyrosine hydroxylase: evidence for regulation of its expression by chronic morphine in the rat locus coeruleus. J. Neurosci. 10, 2649-2659.

Haghparast, A., Khani, A., Lashgari, R., and Fallahian, S. (2008). Reducing the time and dose of morphine application used in Marshall and Grahame-Smith method for induction of morphine tolerance and dependence in mice. Drug Alcohol Depend. 93, 185-189.

Hatami, H., Oryan, S., Semnanian, S., Kazemi, B., Bandepour, M., and Ahmadiani, A. (2007). Alterations of BDNF and NT-3 genes expression in the nucleus paragigantocellularis during morphine dependency and withdrawal. Neuropeptides 41, 321-328.

Hodgson, S. R., Hofford, R. S., Norris, C. J., and Eitan, S. (2008). Increased elevated plus maze open-arm time in mice during naloxone-precipitated morphine withdrawal. Behav Pharmacol 19, 805-811.

Hung, H. C., and Lee, E. H. (1996). The mesolimbic dopaminergic pathway is more resistant than the nigrostriatal dopaminergic pathway to MPTP and $\mathrm{MPP}+$ toxicity: role of BDNF gene expression. Brain Res. Mol. Brain Res. $41,14-26$

Kandel, D. B., Huang, F. Y., and Davies, M. (2001). Comorbidity between patterns of substance use dependence and psychiatric syndromes. Drug Alcohol Depend. 64, 233-241.

Kaplan, D. R. and Miller, F. D. (2000). Neurotrophin signal transduction in the nervous system. Curr. Opin. Neurobiol. 10, 381-391.

Kessler, R. C., McGonagle, K. A., Zhao, S. Nelson, C. B., Hughes, M., Eshleman, S., Wittchen, H. U., and Kendler, K. S. (1994). Lifetime and 12-month prevalence of DSM-III-R psychiatric disorders in the United States. Results from the National Comorbidity Survey. Arch. Gen. Psychiatry 51, 8-19.

Kogan, J.H., Nestler, E. J., and Aghajanian, G. K. (1992). Elevated basal firing rates and enhanced responses to 8Br-cAMP in locus coeruleus neurons in brain slices from opiate-dependent rats. Eur. J. Pharmacol. 211, 47-53.

Koob, G. F. (1992). Neurobiological mechanisms in cocaine and opiate dependence. Res. Publ. Assoc. Res. Nerv. Ment Dis. 70, 79-92.

Kushner, M. G., Abrams, K., and Borchardt, C. (2000). The relationship between anxiety disorders and alcohol use disorders: a review of major perspectives and findings. Clin. Psychol. Rev. 20, 149-171.

Lane-Ladd, S. B., Pineda, J., Boundy, V.A. Pfeuffer, T., Krupinski, J., Aghajanian, G. K., and Nestler, E. J. (1997). CREB 
(cAMP response element-binding protein) in the locus coeruleus: biochemical, physiological, and behavioral evidence for a role in opiate dependence. J. Neurosci. 17, 7890-7901.

Laurenzi, M.A., Barbany, G., Timmusk, T., Lindgren, J. A., and Persson, H. (1994). Expression of mRNA encoding neurotrophins and neurotrophin receptors in rat thymus, spleen tissue and immunocompetent cells. Regulation of neurotrophin- 4 mRNA expression by mitogens and leukotriene B4. Eur. J. Biochem. 223, 733-741.

Liebowitz, M. R., Gorman, J. M., Fyer, A. J., Dillon, D. J., and Klein, D. F. (1984). Effects of naloxone on patients with panic attacks. Am. J. Psychiatry 141, 995-997.

Lindefors, N., Brodin, E., and Metsis, M. (1995). Spatiotemporal selective effects on brain-derived neurotrophic factor and trkB messenger RNA in rat hippocampus by electroconvulsive shock. Neuroscience 65, 661-670.

Maldonado, R. (1997). Participation of noradrenergic pathways in the expression of opiate withdrawal: biochemi$\mathrm{cal}$ and pharmacological evidence. Neurosci. Biobehav. Rev. 21, 91-104.

Maldonado, R., Blendy, J. A., Tzavara, E., Gass, P., Roques, B. P., Hanoune, J., and Schutz, G. (1996). Reduction of morphine abstinence in mice with a mutation in the gene encoding CREB. Science 273, 657-659.

Maldonado, R., and Koob, G. F. (1993). Destruction of the locus coeruleus decreases physical signs of opiate withdrawal. Brain Res. 605, 128-138.

Maremmani, I., Marini, G., and Fornai, F. (1998). Naltrexone-induced panic attacks. Am. J. Psychiatry 155, 447.

Martin, M., Otto, C., Santamarta, M. T., Torrecilla, M., Pineda, J., Schutz, G., and Maldonado, R. (2003). Morphine withdrawal is modified in pituitary adenylate cyclase-activating polypeptide type I-receptor-deficient mice. Brain Res. Mol. Brain Res. 110, 109-118.

Nakai, T., Hayashi, M., Ichihara, K., Wakabayashi, H., and Hoshi, K. (2002). Noradrenaline release in rat locus coeruleus is regulated by both opioid and alpha(2) -adrenoceptors. Pharmacol. Res. 45, 407-412.

Nestler, E. J. and Aghajanian, G. K. (1997). Molecular and cellular basis of addiction. Science 278, 58-63.

Nicolas, L. B., Klein, S., and Prinssen, E. P. (2007). Defensive-like behaviors induced by ultrasound: further pharmacological characterization in Listerhooded rats. Psychopharmacology (Berl.) 194, 243-252.

Numan, S., Lane-Ladd, S. B., Zhang, L., Lundgren, K. H., Russell, D. S. Seroogy, K. B., and Nestler,E. J. (1998).
Differential regulation of neurotrophin and trk receptor mRNAs in catecholaminergic nuclei during chronic opiate treatment and withdrawal. $J$. Neurosci. 18, 10700-10708.

Numan, S., and Seroogy, K. B. (1999). Expression of trkB and trkC mRNAs by adult midbrain dopamine neurons: a double-label in situ hybridization study. J. Comp. Neurol. 403, 295-308.

Pineda, J., Ruiz-Ortega, J.A., Martin-Ruiz, R., and Ugedo, L. (1996). Agmatine does not have activity at alpha 2adrenoceptors which modulate the firing rate of locus coeruleus neurones: an electrophysiological study in rat. Neurosci. Lett. 219, 103-106.

Protopopescu, X., Pan, H., Tuescher, O., Cloitre, M., Goldstein, M., Engelien, A., Yang, Y., Gorman, J., LeDoux, J., and Stern, E. Silbersweig, D. (2006). Increased brainstem volume in panic disorder: a voxel-based morphometric study. Neuroreport 17, 361-363.

Rasmussen, K., and Aghajanian, G. K. (1989). Withdrawal-induced activation of locus coeruleus neurons in opiate-dependent rats: attenuation by lesions of the nucleus paragigantocellularis. Brain Res. 505, 346-350.

Regier, D. A., Farmer, M. E., Rae, D. S., Locke, B.Z., Keith, S. J., Judd, L. L., and Goodwin, F. K. (1990). Comorbidity of mental disorders with alcohol and other drug abuse. Results from the Epidemiologic Catchment Area (ECA) Study. JAMA 264, 2511-2518.

Roller, S. (2000). Consideration, assessment and treatment of difficulty in breathing in palliative medicine. Z. Arztl. Fortbild. Qualitatssich. 94, 579-585.

Ruiz, F., Dierssen, M., Florez, J., and Hurle, M. A. (1993). Potentiation of acute opioid-induced respiratory depression and reversal of tolerance by the calcium antagonist nimodipine in awake rats. Naunyn Schmiedebergs Arch. Pharmacol. 348, 633-637.

Sahún, I., Delgado-Garcia, J. M., AmadorArjona, A., Giralt, A., Alberch, J., Dierssen, M., and Gruart, A. (2007a). Dissociation between CA3-CA1 synaptic plasticity and associative learning in TgNTRK3 transgenic mice. J. Neurosci. 27, 2253-2260.

Sahún, I., Gallego, X., Gratacòs, M., Murtra, P., Trullás, R., Maldonado, R., Estivill, X., and Dierssen, M. (2007b). Differential responses to anxiogenic drugs in a mouse model of panic disorder as revealed by Fos immunocytochemistry in specific areas of the fear circuitry. Amino Acids 33, 677-688.

Schulteis, G., Yackey, M., Risbrough, V., and Koob, G.F.(1998). Anxiogenic-like effects of spontaneous and naloxoneprecipitated opiate withdrawal in the elevated plus-maze. Pharmacol. Biochem. Behav. 60, 727-731.

Seroogy, K. B., Lundgren, K. H., Tran, T. M., Guthrie, K. M., Isackson, P. J., and Gall, C.M. (1994).Dopaminergic neurons in rat ventral midbrain express brain-derived neurotrophic factor and neurotrophin-3 mRNAs. J. Comp. Neurol. 342, 321-334.

Simonin, F., Valverde, O., Smadja, C., Slowe, S., Kitchen, I., Dierich, A., Le Meur, M., Roques, B. P., Maldonado, R., and Kieffer, B.L. (1998). Disruption of the kappa-opioid receptor gene in mice enhances sensitivity to chemical visceral pain, impairs pharmacological actions of the selective kappaagonist $\mathrm{U}-50,488 \mathrm{H}$ and attenuates morphine withdrawal. EMBO J. 17, 886-897.

Sinha, S. S., Goetz, R. R., and Klein, D. F. (2007). Physiological and behavioral effects of naloxone and lactate in normal volunteers with relevance to the pathophysiology of panic disorder. Psychiatry Res. 149, 309-314.

Sklair-Tavron, L., and Nestler, E. J. (1995) Opposing effects of morphine and the neurotrophins, NT-3, NT-4, and BDNF, on locus coeruleus neurons in vitro. Brain Res. 702, 117-125.

Sklair-Tavron, L., Shi, W. X., Lane, S. B., Harris, H. W., Bunney, B. S., and Nestler, E. J. (1996). Chronic morphine induces visible changes in the morphology of mesolimbic dopamine neurons. Proc. Natl. Acad. Sci. U.S.A. 93, 11202-11207.

Smith, M. A., Makino, S., Altemus, M. Michelson, D., Hong, S. K., Kvetnansky, R., and Post, R. M. (1995). Stress and antidepressants differentially regulate neurotrophin 3 mRNA expression in the locus coeruleus. Proc. Natl. Acad. Sci. U.S.A. 92, 8788-8792.

Strahlendorf, H. K., Strahlendorf, J. C., and Barnes, C. D. (1980). Endorphin-mediated inhibition of locus coeruleus neurons. Brain Res. 191, 284-288.

Taylor, J. R., Elsworth, J. D., Garcia, E. J., Grant, S. J., Roth, R. H., and Redmond, D. E. Jr. (1988). Clonidine infusions into the locus coeruleus attenuate behavioral and neurochemical changes associated with naloxone-precipitated withdrawal. Psychopharmacology (Berl.) 96, 121-134.

Teng, K. K., and Hempstead, B. L. (2004) Neurotrophins and their receptors: signaling trios in complex biological systems. Cell. Mol. Life Sci. 61, 35-48.

Valenca, A. M., Nardi, A. E., Mezzasalma, M. A., Nascimento, I., Lopes, F. L., Zin, W. A., and Versiani, M. (2004). Clonidine in respiratory panic disorder subtype. Arq. Neuropsiquiatr. 62, 396-398.
Van Bockstaele, E. J., Saunders, A., Commons, K. G., Liu, X. B., and Peoples, J. (2000). Evidence for coexistence of enkephalin and glutamate in axon terminals and cellular sites for functional interactions of their receptors in the rat locus coeruleus.J. Comp. Neurol. 417, 103-114.

Williams, J. T., and North, R. A. (1984). Opiate-receptor interactions on single locus coeruleus neurones. Mol. Pharmacol. 26, 489-497.

Zhang, C., Guo, Y. Q., Qiao, J. T., and Dafny, N. (1998). Locus coeruleus modulates thalamic nociceptive responses via adrenoceptors. Brain Res. 784, 116-122.

Zhang, H., Ozbay, F., Lappalainen, J., Kranzler, H. R., van Dyck, C. H., Charney, D. S., Price, L. H., Southwick, S., Yang, B. Z., Rasmussen, A., and Gelernter, J. (2006). Brain derived neurotrophic factor (BDNF) gene variants and Alzheimer's disease, affective disorders, posttraumatic stress disorder, schizophrenia, and substance dependence. Am. J. Med. Genet. B Neuropsychiatr. Genet. 141, 387-393.

Zvolensky, M. J., Bernstein, A., Marshall, E. C., and Feldner, M. T. (2006). Panic attacks, panic disorder, and agoraphobia: associations with substance use, abuse, and dependence. Curr. Psychiatry Rep. 8, 279-285.

Zvolensky, M. J., Feldner, M. T., LeenFeldner, E. W., and McLeish, A. C. (2005). Smoking and panic attacks, panic disorder, and agoraphobia: a review of the empirical literature. Clin. Psychol. Rev. 25, 761-789.

Conflict of Interest Statement: The authors declare that research was conducted in the absence of any commercial or financial relationships that could be constructed as a potential conflict of interest.

Received: 09 April 2009; paper pending published: 07 June 2009; accepted: 16 December 2009; published online: 22 February 2010.

Citation: Gallego X, Murtra P, Zamalloa T, Canals JM, Pineda J, Amador-Ariona $A$, Maldonado $R$ and Dierssen $M$ (2010) Increased opioid dependence in a mouse model of panic disorder. Front. Behav. Neurosci. 3:60. doi: 10.3389. neuro.08.060.2009

Copyright (ㅇ 2010 Gallego, Murtra, Zamalloa, Canals, Pineda, AmadorArjona, Maldonado and Dierssen. This is an open-access article subject to an exclusive license agreement between the authors and the Frontiers Research Foundation, which permits unrestricted use, distribution, and reproduction in any medium, provided the original authors and source are credited. 